\title{
To Endure: \\ An Exploration of Male Rape in the Declamatory Cases of Pseudo-Quintilian $\&$ Seneca the Elder
}

\section{Jakob McCaffrey}

Submitted in fulfilment of the requirements for the degree of Master of Arts in Classical Studies

Victoria University of Wellington 


\section{CONTENTS}

INTRODUCTION

\section{CHAPTER ONE: SETTING THE SCENE}

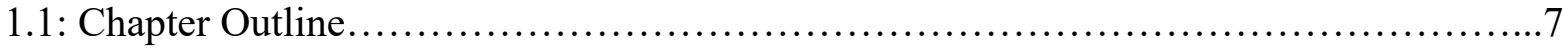

1.2: Defining Declamation...........................................................

1.3: The Purpose of Declamation...............................................11

1.4: Defining Homosexuality in a Classical Context.................................. 15

1.5: Exploring Rape in a Classical Context.......................................20

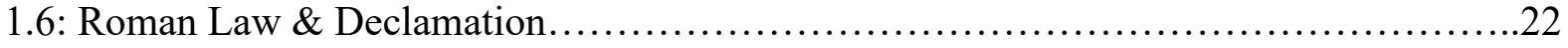

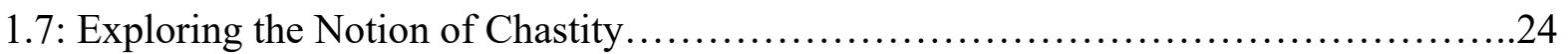

\section{CHAPTER TWO: PSEUDO-QUITNILIAN'S MAJOR DECLAMATIONS 3}

2.1: Background on Pseudo-Quintilian........................................... 31

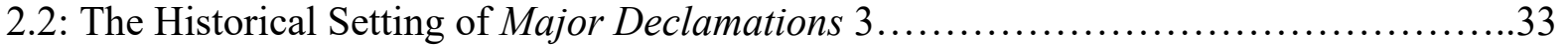

2.3: Breakdown of the Source.........................................................

2.4: The Representation of Lusius............................................40

2.5: The Representation of Trebonius............................................. 43

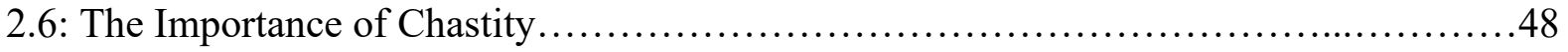

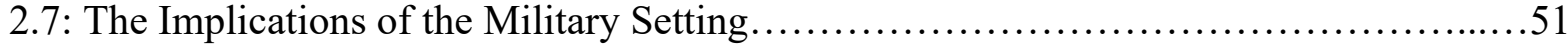

2.8: Final Thoughts............................................................. 55 
CHAPTER THREE: SENECA THE ELDER'S CONTROVERSIAE 5.6

3.1: Background on Seneca the Elder..........................................57

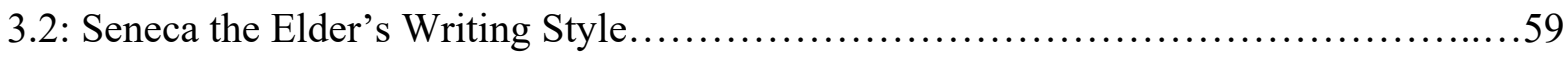

3.3: Breakdown of the Source................................................61

3.4: The Case Against the Victim...................................................64

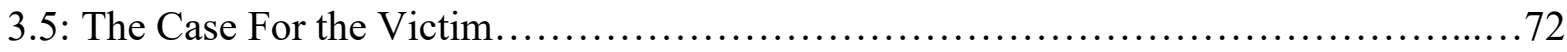

3.6: Final Thoughts....................................................... 74

\section{CHAPTER 4: SOURCE COMPARISONS \& MODERN PARALLELS}

4.1: Analysis of Pseudo-Quintilian \& Seneca the Elder............................... 75

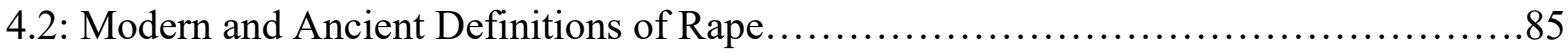

4.3: Comparisons Between Modern Ideology and the Controversiae.....................90

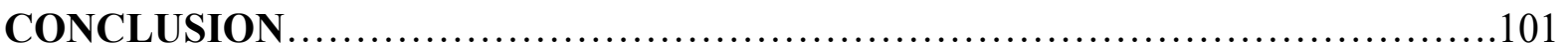

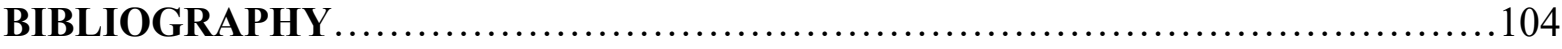




\section{INTRODUCTION}

'Fuck you, boys, up the butt and in the mouth, your queer Aurelius and you fag Furius! ... because you happen to read about "many thousands of kisses", you think I'm not a man? Fuck you, boys, up the butt and in the mouth!'

(Catullus Carmen 16 [trans. Micaela Janan 1994 p.45]).

The above quote is taken from the writings of Catullus, detailing what Chrystal refers to as one of the most notorious and celebrated descriptions of male sexual assault within ancient Rome. ${ }^{1}$ It is unsurprising that Chrystal would highlight this work in his book In Bed with the Romans as Catullus' words illustrate the fact that the threat of male sexual assault was very real in the ancient world with it being utilised as a form of physical and political intimidation. ${ }^{2}$

When exploring the definitions for rape in ancient Rome, Nguyen's article 'Roman Rape: An Overview of Roman Rape Laws from the Republican Period to Justinian's Reign' expressed the following: 'One legal charge for rape was vis, which was a crime for physical assault including for purposes of lust. Another legal charge covering rape was stuprum, which covered any irregular or promiscuous sexual act including acquaintance rape, seduction, and homosexuality, as well as forcible rape.' 3 These two terms, and the definitions for these terms, shall remain important throughout this thesis and the exploration of male rape. For the time being, it will suffice to say that this quote clearly shows the various perspectives that are inherent to the way in which the Roman people viewed sexual assault, particularly when it pertained to a male.

\footnotetext{
${ }^{1}$ Chrystal 2015: 161

${ }^{2}$ Chrystal 2015: 162

${ }^{3}$ Nguyen 2006: 83
} 
The purpose of this thesis is to explore the representation of male rape within Roman thought through the analysis of two controversiae, these being Pseudo-Quintilian's Major Declamations 3 and Seneca the Elder's Controversiae 5.6. To this end, the thesis shall be broken into four chapters each with the following goals:

Chapter one shall focus on offering the definitions and terminology for the thesis as a whole, with particular attention being placed on the utilisation of and purpose of declamatory sources within modern scholarship.

Following this, chapter two shall be dedicated to an analysis of the way in which male rape is addressed with Pseudo-Quintilian's Major Declamation 3 with the focus being on the characters, setting and morals explored within this source.

In a similar fashion to chapter two, chapter three will be focused on the representation of male rape in a particular primary source, this being Seneca the Elder's Controversiae 5.6. The focus of this chapter shall be on the way in which the victim is represented and the disparity between the points defending him and those attacking him.

The final chapter, chapter four shall consist of two distinct sections. The first of these shall be a cross-examination of the similarities and differences found between the two primary sources explored in chapters two and three. The second shall be exploring the way in which these sources have discussed male rape and the parallels they have to the way in which modernity addresses this notion. 
The overall purpose of this thesis is to shed light on a previously underutilised form of primary source, declamation. Moreover, by having a work solely focused on victims of male rape, this thesis endeavours to explore why this form of rape is discussed far less than its female counterpart and provide evidence as to why this should be rectified by scholarship moving forward. Ultimately, this thesis is focused on serving as a steppingstone for other scholars to see worth in the sources and themes that it addresses whilst also providing satisfactory conclusions to what it discusses. 


\section{CHAPTER ONE:}

\section{SETTING THE SCENE}

\section{1: Chapter Outline}

The purpose of this first chapter is to lay down the groundwork for the way in which this thesis shall approach several key concepts that shall recur throughout. To this end this chapter shall examine the following five distinct areas with particular attention being placed on the following aspects. The first of these is to define declamation with detail being placed on the type of declamatory cases that shall be explored within this thesis and a discussion of the place that declamation holds within modern scholarship and analysis. Secondly, there shall be an exploration of the way in which modern terminology surrounding gender identity, notably homosexuality, applies to studies of the ancient world and the utilisation of such terminology in these studies. Thirdly an examination of the definitions of rape in a classical context shall occur in order to inform the reader of the way in which these definitions can differ from modern sensibilities. Fourthly, a brief discussion of the intersection between Roman law and declamation shall occur. Finally, this chapter shall conclude with an analysis of the way in which the value of chastity was of chief importance to the Roman people and the degree to which they allowed this notion to govern their sensibilities. Overall, the purpose of this chapter shall be to familiarise the reader with the appropriate themes, ideology and terminology that shall remain relevant throughout this thesis. 


\section{2: Defining Declamation}

Before diving into an examination of the declamation cases detailed within Pseudo-Quintilian and Seneca the Elder it is worth addressing the framework within which declamation operated and the overall place that it held within Roman society.

Seneca the Elder himself will attest to the fact that declamation was a form of rhetoric that both originated and developed within his own lifetime. This sentiment is expressed in the elder Seneca's preface to his first book of controversiae stating: 'The name [this being controversiae] has emerged recently, the practice itself having become popular not long ago: the thing was born after me - that is why it is easy for me to know it from its cradle. (Seneca the Elder Controversiae 1.12 [trans. Winterbottom 1974 p.13]). ${ }^{4}$ But we need not take Seneca's word for it. Scholars such as Russell have demonstrated that this claim does not explain the true origins of declamation, for controversiae are a species of declamation, and has merely served to confuse scholars analysing such work. ${ }^{5}$ The reality of the situation is that, like many keystone characteristics of the Roman Republic and Empire, the lineage of declamation can be traced back to Hellenistic Greece with it rising to prominence as a form of rhetorical education in the third century BCE. ${ }^{6}$ The origins of this, being referred to as proto-declamation, are found within works such as Antiphon's Tetralogies. ${ }^{7}$ Moreover, rather than being a rhetorical fad whose influence was felt only during these early stages of the Roman Empire, there are examples of declamatory cases lasting within both the Greek East and Latin West until the Middle Ages ${ }^{8}$.

\footnotetext{
${ }^{4}$ This quote has been edited by me.

${ }^{5}$ Russell 1996: 6

${ }^{6}$ Gunderson 2003: 2

${ }^{7}$ Russell 1996: 5 A further list of proto-declamation examples can be found here for those curious.

${ }^{8}$ Gunderson 2003: 2
} 
Regardless of its origins, declamation quickly cemented its place as not only an important rhetorical movement within the newly transitioned Roman Empire but as arguably the first key literary movement of it. ${ }^{9}$ Before the time of the Empire it is clear that declamation did have a presence however the status of it as a legitimate teaching tool was often questioned and occasionally even mocked. ${ }^{10}$ It is stated that a young Cicero himself was advised against continuing his training at the school of Plotius Gallus, a school that was described as having its students practice fictional cases that imitated real notions of speech and legal practice, by Lucius Crassus (Cicero De Oratore 3.93 \& Brutus 169). Whilst this school did not specifically practice declamation, or at least not declamation in the form that it would later be known, it is clear that what was done at this school does fit a rudimentary definition of what declamation came to entail and therefore it would be reasonable to assume that this school did serve as a foundation for what declamation would evolve into over the years. ${ }^{11}$ Later in his career Cicero even went about making various comments criticising the growing popularity and deployment of declamation as a form of both literature and oratory.

Despite this initial distaste towards the practice, it is clear that by the time of the early Roman Empire declamation was a cornerstone of political and legal training with renowned rhetoricians such as the elder Seneca and Quintilian ${ }^{12}$ having schools specifically utilising declamation as a key part of rhetorical training.

When it comes to defining declamation a succinct definition is offered by Dinter when he stated 'They (this being declamation) discuss (in all seriousness) fictional court cases so as to provide

\footnotetext{
${ }^{9}$ Bloomer 2007: 297

${ }^{10}$ Bonner 1949: 16-19

${ }^{11}$ Winterbottom 1974: vii-x

${ }^{12}$ Note that this is referring to the historical Quintilian not the Pseudo-Quintilian who has been attributed with writing the Major Declamations that this thesis shall be exploring.
} 
training to future lawyers and display a framework of rhetorical skill., ${ }^{13}$ Whilst this definition does provide an elegant summary of the general notion of declamation it does ignore various details surrounding the topic, the most imminent of these being the fact that there are actually two forms of declamation, these being suasoria and controversia. ${ }^{14}$ Suasoria was seen as the more elementary level of declamation in which students would imagine themselves as fictitious advisers to famous historical figures. ${ }^{15}$ Examples include such topics as "should Cato marry?" (Quintilian Institutio Oratoria 3.5.13) and "should Alexander at the edge of the known and conquered world set sail upon the ocean?” (Seneca the Elder Suasoriae 1.1). In contrast, controversia was considered to be the more elite and nuanced form of declamation, easily described as a mock legal speech which set the speaker as an advocate of the deposed or as the champion of an injured and outraged family and state. ${ }^{16}$ The disparities required in the orator's skill between both forms of declamation is succinctly summarised in Bloomer's chapter 'Roman Declamation: The Elder Seneca and Quintilian': 'The suasoria thus required a narrative with the occasional apostrophe, whereas the controversia would introduce a number of speaking parts and demand a variety of perspectives' ${ }^{17}$.

This second form of declamation, controversia, encompasses both of the declamation cases that this thesis is examining, these being the case of 'The Man who was Raped in Women's Clothes' detailed within Seneca the Elder's aptly named Controversiae and 'The Case of the Solider in the Army of Marius' detailed within Pseudo-Quintilian's Major Declamations. It is therefore the definition and understanding of a controversia and the nuances of this rhetorical form that are of chief importance to the reader going forward.

\footnotetext{
${ }^{13}$ Dinter 2015: 1 . Note that the brackets in this quote are a direct translation and not an addition on my end.

${ }^{14}$ Gunderson 2003: 1

${ }^{15}$ Bablitz 2007: 2

${ }^{16}$ Bablitz 2007: 2

${ }^{17}$ Bloomer 2007: 301
} 


\section{3: The Purpose of Declamation}

Now that an understanding of declamation has been established a discussion detailing the purpose and significance of it must commence. Due to the nature of the way in which declamation was taught, being used as a tool for further educating the elite amongst Rome's youths in the ways of Roman rhetoric, ${ }^{18}$ coupled with the subject matter upon which declamation addressed, these being court cases exploring a range of topics situated around issues of law, it would not be unreasonable to initially assume that declamation worked as essentially a stand in for the real-life court cases and legal trials that one would face throughout their life. Based upon this assumption the next reasonable thing to believe would be that declamation in both of its forms took place in, for want of a better term, the real world with all of the cases detailing actual laws, regulations and ideologies of Roman society. The reality of declamation is far more nuanced and complex however, all declamation cases took place in a fictionalised city and society, one which Russell gave the title of Sophistopolis. ${ }^{19}$ According to Russel, this city-state like structure was described as being a small, independently governed Hellenistic community in which all manner of crimes and atrocities took place. Based upon the fact that declamation was therefore removed from Roman society and law, many scholars, including Crook, have argued the point that declamation had no basis in actual Roman law and therefore cannot be used as a lens through which one can analyse the laws of the Roman people. ${ }^{20}$ Moreover, scholars such as Bloomer have argued that declamation as an overall practice was one of little significance as it was essentially solely practiced by the likes of schoolboys with his arguments reducing the genre down to the notion of mere schoolboy antics. $^{21}$

\footnotetext{
${ }^{18}$ Bloomer 2007: 298-299

${ }^{19}$ Russell 1983: 21-39

${ }^{20}$ Crook, 1995: 165

${ }^{21}$ Bloomer 1997b: 64-67
} 
Whilst one must be careful to never overstate the importance of sources that clearly do have a level of separation, particularly when it comes to ancient sources which are often fragmented at best, it would be a disservice to state that there is no correlation between the declamation being examined and the laws and social morals of the early Roman Empire.

In a direct response to Bloomer's assertions, Gunderson illustrates the idea that declamation can be reduced down to schoolboy antics by comparing it to the contemporary analogue of detective fiction. ${ }^{22}$ Gunderson argues that detective fiction is not considered highbrow by today's audience however it would be folly to state that it is a form of work only designed for the young members of society. ${ }^{23}$ In a similar fashion, reducing declamation down to this mere schoolboy mentality deeply damages and diminishes the nuance and importance of this rhetorical form. ${ }^{24}$ It appears that Gunderson's seminal work on declamation and others that followed it have had an effect on the way in which this field of scholarship is viewed as, ten years after his reduction of declamation to mere schoolboy antics, Bloomer now confidently proclaims in a defence of declamation that: 'The relation of declamation to Roman law, in addition to being the common training shared by every lawyer and by a citizen jury pool, is perhaps the relation of beneficium and officium to legal contract, that is, social obligations and roles to legal obligations and roles. ${ }^{25}$

This is to say that Roman declamation, being a tool that was used by the vast majority and having a place that extended beyond mere training and also served as a form of entertainment amongst the elite, clearly would have reflected the values and attitudes that the Roman people would have had to the issues that it addresses. This level of connection and reflection would have been present as without it the whole process of declamation would have been largely

\footnotetext{
22 Gunderson 2003: 2-3

${ }^{23}$ Gunderson 2003: 3

${ }^{24}$ Gunderson 2003: 3

25 Bloomer 2007: 305
} 
useless at preparing one for real-life cases. Moreover, those who practiced declamation, without any societal parallel, would have been incapable of passing down the moral judgement and opinions that such oratory performances required of their speakers. Bernstein supports this sentiment when he stated that: 'The declamatory performance does not, however, effect change in the real world in the direct manner of a plea in a forensic court. Rather, the declaimer's plea directs the audience to assess ethical claims. ${ }^{26}$

It is no accident that the cases detailed within declamation of any form often deal with some of the most heinous, horrific or merely complicated scenarios that one could ever come across and due to this declamation served more as an examination of Roman life pushed to an extreme far beyond the norm of day to day life. Ultimately it is apparent that declamation was no mere one to one analysis of the Roman legal system and the nuanced laws within or that every aspect of it paralleled Roman society at the time of its creation. However, it is fair to argue the importance of declamation as a comparative tool through which, once all of the extreme and frankly absurd notions it addresses are pushed aside, one can glean a parallel to the morals and opinions of the Roman people at this point in time. This ideology is best summarised by Gunderson when he simply stated: 'If we are to know the Romans than we must read their declamation. ${ }^{27}$

Moreover, from a level directly solely applying to the performers of declamation, it had a place in asserting the status of a member of the Roman elite as it 'continued some of the social function of Roman oratory by forecasting the stars of the coming generation and by ranking and re-ranking professional speakers. ${ }^{28}$ This is to say that, even if declamation did have a degree of separation, legally speaking, from the early Roman Empire the importance of this

\footnotetext{
${ }^{26}$ Bernstein 2013: 5

${ }^{27}$ Gunderson 2003: 25

${ }^{28}$ Bloomer 2007: 298
} 
type of oratory was well known amongst the established and aspiring elite with many going out of their way to demonstrate their superior literary, oratorical and legal skill through the art of performing declamation. Essentially, stepping aside from the claim that declamation had no societal or legal basis, which this thesis has argued against, it is clear that even with no explicit connection, dismissing declamation as nothing more than a basic form of practice for those without the skill or ability to properly compete in the political arenas of Rome would be a mistake and misinterpretation of this highly nuanced, political and skilled-based performance art.

As hinted at earlier, declamation cases often dealt with scenarios in which the worst atrocities imaginable took place. Examples of these include such taboos as cannibalism (PseudoQuintilian Major Declamations 12), incest (Pseudo-Quintilian Major Declamations 18), torture (Seneca the Elder Controversiae 2.5), suicide (Seneca the Elder Controversiae 5.1) and patricide (Seneca the Elder Controversiae 9.6). Connolly argued that the deployment of such heinous scenarios was done deliberately as declamation allowed the Roman people to look at a society, Sophistopolis, that had examples of similar Roman cases and concerns that were taken to the extreme. ${ }^{29}$ This is to say that through examining a notional society that was, as has been established, detached from Roman society, but with a number of parallels in terms of status, legal attitudes and societal concerns, the provider of this declamatory speech and the audience could comfortably ask themselves the difficult questions of how to deal with such scenarios. Moreover, declamation had the added comfort of allowing one to ask these difficult and often troubling societal questions whilst being safe in the knowledge that, even with the most extreme and obvious of parallels, they were living in a society that was far safer and dignified than this almost dystopian-like parallel.

${ }^{29}$ Connolly 2015: 193 
All in all, declamation was a tool of great importance to the Roman people, particularly in the early stages of the Empire. Declamation served several key purposes from training both the would be and active political and legal elite of Rome, to allowing those present to any declamation performance to question their own societal morality and finally as a key tool for establishing one's oratorical and legal prowess in the face of their peers. Declamation, ultimately, was a vital part of the Roman elite's ecosystem and is, to this day a tool for analysis through which one can carefully glean a further understanding of the societal, political and legal norms and values of Rome during this time.

\section{4: Defining Homosexuality in a Classical Context}

Before proceeding to the representation and realities of male rape it is necessary to address the way in which the Romans viewed homosexuality. Firstly, the term homosexual, that being a man who is attracted to and engages in sexual relations with another man, is not a term that the Romans would have had any familiarity with or a concern over ${ }^{30}$ Frankly all of the modern definitions of one's sexual preferences, heterosexual, homosexual, bisexual, pansexual etc. are terms that really have no place in a discussion on Roman sexual preferences and attitudes. Unfortunately, due to the sensibilities of the modern reader, removing such terms from any discussion is greatly difficult with the majority of books discussing said preferences having titles including this terminology. ${ }^{31}$ Many of these books then proceed to include a discussion much like this detailing the difficulty of using modern terminology in an ancient context.

\footnotetext{
${ }^{30}$ Williams 2010: 4-9

${ }^{31}$ Just a couple of examples include Thomas K. Hubbard's Homosexuality in Greece and Rome, Craig A.

Williams' Roman Homosexuality and Eva Cantarella's Bisexuality in the Ancient World.
} 
Arguably one of the chief causes of this difficulty comes from a notion of accessibility, all modern readers shall understand the terms homosexual and heterosexual however far fewer will be familiar with such terms as fututores and pathici. ${ }^{32}$ Based upon this assumption, and in order to ensure ease for the reader's comprehension the deployment of such terms can often become an unfortunate necessity. Moreover, the reason why these terms have garnered such use is that there is a fair, if uneducated, assumption these terms do in fact have a place in describing the various forms of Roman sexuality as they appear to be rather universal terms. Surely if a Roman man is described as only enjoying the company of males than it should be acceptable to define him as homosexual, with the same holding true for the various other defining terms for sexuality. Some scholars have even taken this a step further and have looked to the past in order to understand the origins of such sexualities and their modern-day treatment. ${ }^{33}$ Unfortunately, deployment of such tactics can easily lead to a misunderstanding of the various fascinating nuances that can be seen in the various forms of Roman sexuality. Despite these inherent issues the deployment of such terms, notably homosexuality, is a necessary evil that this thesis shall begrudgingly accept. To this end, a brief address of what it meant to be a Roman man, from the viewpoint of sexual preference, is prudent.

As stated above, to the Romans a study of homosexuality, as well as any of the modern definitions of sexuality, would have been seen as ridiculous. What was of chief importance to a Roman man (note in this case a Roman man is referring to a freeborn citizen) is exactly that, they were seen as a man or rather as a vir. When it came to preference of sexual partner the complexities did not arise in what gender that partner was but rather which position they held

\footnotetext{
${ }^{32}$ Halperin 2002: 243-244

${ }^{33}$ See Robert H. Allen's The Classical Origins of Modern Homophobia a book that attempts to offer classical cases as explanations for the way in which the modern homophobia came about. Whilst this notion is not a bad one to explore the book unfortunately fails to comprehensively address the issue of applying the term homophobia to ancient cases, a rather glaring oversight.
} 
within society and what actions you allowed yourself and your partner to engage in. ${ }^{34}$ In relation to the notion of status, being a highly class-based society, it is perhaps no wonder that whether a sexual act was seen as perverse was often dictated by the class of the person with whom a Roman man was intimate with. When it came to other Roman citizens that were not your wife, sexual relations of any kind were deemed to be unacceptable behaviour with charges of stuprum and moral depravity being laid against those who ignored this social guideline. ${ }^{35}$ All of this essentially came down to the notion of status and anyone who had obtained the status of a Roman citizen was therefore considered to be of a superior nature to those without, thus making any violation against them a violation of Roman superiority itself. ${ }^{36}$ It is also worth noting that the notion of someone being, for want of a better term "off limits" due to their status was one that was universal regardless of circumstance. Essentially it did not matter whether the intercourse that occurred was part of a continued relationship or a one-time occurrence, nor did the notion of consent matter in terms of supporting this relationship. If anyone was seen violating these regulations, they were open to the penalties listed above. Notably, for the purposes of this thesis' examinations, the rape of a Roman citizen was, naturally, considered an even greater offence than a consenting relationship that was deemed "off limits". 37

By stark contrast, anyone who was not a Roman citizen was largely considered to be acceptable options for sexual relations, regardless of gender. The most common acceptable examples of a person for a Roman citizen to have unrestricted intercourse with are prostitutes or their own slaves. ${ }^{38}$ These two options were considered to be the ones which would guarantee a certain

\footnotetext{
34 Skinner 2005: 19

35 Ormand 2009: 176

${ }^{36}$ Walters 1997: 29-30

${ }^{37}$ Williams 2010: 130-133

${ }^{38}$ Younger 2005: 125-126
} 
level of public safety as, due to their status and level of ownership, there was inherently no issue in having relations with either a prostitute, someone who was willing to sell their body for profits and obviously not having the status of Roman citizen ${ }^{39}$, and one's own slave ${ }^{40}$, their rightful property with which one could do as they pleased without fear of repercussions. ${ }^{41}$ Perhaps surprisingly, not all slaves were considered to be acceptable options for sexual relations. In fact, any slave that was not explicitly your property was deemed to be off-limits as the, being someone else's property, were deemed to be damaged in some capacity if another citizen had relations with them. Chrystal explored how such notions fell under the laws surrounding property damage rather than those addressed issues of stuprum such as the Lex Scantinia. $^{42}$

As stated above, it was not only the status of the partner that was in question when it came to proving one's masculine status, there was also the issue of what acts were performed in any given sexual encounter and, most importantly, who performed those actions. ${ }^{43}$ Put plainly, there were certain actions that were considered to be effeminate and not masculine, that were expected never to be performed by any Roman male citizen. Commonly it has been illustrated that these actions were centred around the act of penetration, with the person being penetrated not being the man. Whilst such actions as pedicones (anal penetrators, note this is a nongendered term so it could be used to refer the anal penetration of either a man or a woman) and irrumatores (oral penetrators, similar to pedicones in that it is non-gendered terminology)

\footnotetext{
${ }^{39}$ Williams 2010: 40

${ }^{40}$ See Lewis 2015: 152-156 for an exploration on the status, or lack thereof, that slaves held within Roman society.

${ }^{41}$ Obviously, following these rules does not mean that one, particularly a Roman elite of political status and importance, would have been immune to any form of vituperatio against their character due to engaging in sexual relations with either their slave or a prostitute. The Roman elite rather infamously attacked any perceived character flaw they could within their allies, no matter how far-fetched or removed from reality these claims actually were. However, the basis of these attacks would have been centred around issues surrounding masculinity and other such claims rather than issues of who the Roman citizen in question was having sex with. ${ }^{42}$ Chrystal 2015: 158

${ }^{43}$ Kamen and Levin Richardson 2014: 449-450
} 
being immoral acts to take part in if you were the one being penetrated. ${ }^{44}$ Notably, these actions were deemed to be so shameful to perform that certain terms of ridicule and mockery exist, the first of these is the term fellatores (to describe a man, or rather in the view of the Roman people a non-man, who used his mouth to provide sexual pleasure for others, or put plainly: same sex male oral penetration). Moreover, the terms pathici and cinaedi were used to describe and ridicule those who gave away their own masculine autonomy by allowing themselves to be anally penetrated by other men. These notions of public shaming were clearly centred around what scholars such as Williams have identified as the penetrative paradigm, this being the term that is given to the notion that all male sexual interactions were predicated on the notion of who was penetrating whom. ${ }^{45}$ Overall, it is clear that, for a proper male Roman citizen, being penetrated in any capacity was shameful as it was the male, being the active in any sexual scenario, that must be the penetrator.

It is worth noting that this notion of the penetrator being the person who is active in any sexual scenario, and by association the receiver being the passive participant, does not hold the same universal acceptance as it did even a few decades ago. Recent scholarship, notably works such as Kamen and Levin-Richardson's 'Revisiting Roman Sexuality', have argued for and demonstrated evidence of the manoeuvrability for these positions being reversed. This being due to evidence that at times there could be sexual encounters that were predicated on the notion of a passive penetrator and an active receiver or, as Kamen and Levin-Richardson describe, the idea of passivity vs. activity. ${ }^{46}$ Whilst this recent reinterpretation of pre-conceived notions of sexuality in the ancient world is a fascinating argument, the ramifications of which are far-reaching and worthy of study and further examination, for the purposes of this thesis

\footnotetext{
${ }^{44}$ Williams 2010: 137

45 Williams 2010: 258-262

${ }^{46}$ Kamen and Levin Richardson 2014: 455-456
} 
these notions need not apply. This is due to the simple fact that all of the sexual encounters that shall be detailed within this thesis are instances of rape, an act that, due to its very nature, does not allow for the nuances of who is the active and the passive to be explored. Put plainly when rape is concerned, the traditional notion of the penetrator being the active participant and the receiver being the passive (rather unwilling) participant holds more than true and is the framework within which this thesis shall explore.

All of this is to demonstrate the idea that, when it comes to notions of maintaining the proper masculine image what one did in their sexual encounters and whom they participated with are of chief importance. As shall be explored throughout this thesis the idea of someone being raped does inherently negatively impact their masculine image as they become the receiver in an unwilling sexual experience thus challenging their overall masculine standing as someone who was too weak to defend their own manhood.

\section{5: Exploring Rape in a Classical Context}

The next area to address is that of the way in which rape was defined and perceived in the classical context. An idea that shall be addressed time and time again in this thesis is the fact that a rape, at least by the modern understanding of the term, was only considered as such if it occurred to a Roman citizen. Interestingly, one legally could not rape their own slave (they were their own property after all) and if one raped another person's slave the only legal actions that could be taken against them fell under issues of property damage, particularly the laws of Lex Aquilia with the focus being on the sexual integrity of the slave, not any physical or emotional damage that could have resulted as part of the rape. ${ }^{47}$

${ }^{47}$ McGinn 1998: 314 
In a similar way to when this thesis analysed the term homosexual, the Romans did not appear to have a direct one to one comparative term that detailed what the modern term rape entails. Applying the term rape to ancient studies is nowhere near as problematic as using the term homosexual as the Romans did at least have some facsimile to what the modern term rape entails. Whilst one might assume that the term raptus (or raptio) would be this facsimile, due to its linguistic similarity to the modern term rape, it instead details an act of kidnapping or abduction rather than sexual violation. ${ }^{48}$ Arguably one of the best terms to use would be that of stuprum which could be a generalised term for forced sex, the additions of cum vi or per vi could then be included to define this forced sex more specifically as with violent force. ${ }^{49}$

It is apparent that the idea of rape and violence were closely associated with one of the most famous examples of violent rape coming from Catullus' Carmen 16 which, as detailed in this thesis' introduction, details threats of oral and anal rape from one Roman citizen to another. To say that these threats imply violence would be an understatement with direct reference to clearly non-consensual face fucking and arse fucking occurring in order for Catullus to assert his masculine dominance over his opponents. ${ }^{50}$ Due to the early discussion on homosexuality and masculinity it is perhaps unsurprising that discourse surrounding male rape takes on this very aggressive and forceful language as it was one of the ultimate displays of masculine power, both physically and sexually overpowering another male citizen. Richlin's work Not Before Homosexuality briefly touches upon a general concern surrounding being dominated in such a way and fears of being labelled infames because of it. ${ }^{51}$

\footnotetext{
${ }^{48}$ Harries 2007: 86

${ }^{49}$ Chrystal 2015: 157-159

${ }^{50}$ Chrystal 2015: 161

${ }^{51}$ Richlin 1994: 555-561
} 
Whilst the nuances of the impacts of rape, notably of raping a male citizen, shall be explored in far greater detail throughout this thesis it is worth having briefly addressed the idea of the terminology surrounding rape and some of the basic concerns and attitudes towards it in order to provide the reader with a base framework for the more detailed conversations to follow.

\section{6: Roman Law \& Declamation}

It is now worth briefly spending some time addressing the way in which Roman law and the laws outlined in declamatory cases intersect. As has been outlined earlier, a chief criticism amongst scholars ${ }^{52}$ as to why declamations should not be taken seriously is that they are situated in a largely fictionalised space. As Gunderson outlines: 'declamations themselves obey this same logic: they forever cite an authority that is only hypothetical; they defend a law that has been conjured for the occasion; and they champion the values of an imagined community. ${ }^{53}$ This obviously creates a divide when approaching the laws found within declamations and applying them to analysis of the Roman world.

In response to these issues' scholars have provided a number of solutions for understanding the laws found within declamations. These include scholars like Berti ${ }^{54}$ who have attempted to provide ways of approaching this divide, most notably with the notion of status-theory ${ }^{55}$ and works such as Breij have simply analysed the laws' function within the declamation cases they pertain to. ${ }^{56}$ Despite the merit of such works, and the overall field of analysing the laws within declamatory works, it is perhaps unsurprising that Gunderson offers the best approach for

\footnotetext{
${ }^{52}$ Langer 2007: 17-30 offers an excellent survey of scholarly opinions relating to the issues of law and declamation.

${ }^{53}$ Gunderson 2003: 57

${ }^{54}$ Berti 2015: 7-8

${ }^{55}$ See Calboli Montefusco 1986 for a general overview of status-theory

${ }^{56}$ Breij 2015: 219-221
} 
dealing with the laws found within the declamatory cases that this thesis shall be examining, this being the fact that: 'in a declamation one often does leave the law somewhat to the side. ${ }^{57}$ This notion is further elaborated upon by Roller when he argues that: '[In] declamation a moral understanding of events is the primary mode of understanding; ethical appeals are more authoritative and persuasive than appeals on any other grounds. ${ }^{58}$ All of this is to illustrate the point that an analysis of the laws stated within Major Declamations 3 and Controversiae 5.6 shall largely be ignored.

This is due, in a small part, to the inherent complexities of analysing declamatory laws. However, the main reason for this decision is the simple fact that such a discussion would do far more to distract one from the central points of this thesis, which are 1) the representation of male rape in Roman declamation and 2) the way in which this representation parallels with modern sensibilities. Whilst the laws detailed shall obviously be relevant to some degree to the declamatory cases overall, these laws shall largely be taken at face value with the bulk of this thesis focusing upon the implications that these laws have rather than the specific details of the laws themselves. ${ }^{59}$ Instead this thesis will focus on exploring the social ramifications that these declamatory circumstances have had on the victims found within. Put plainly, instead of analysing the complexities of the law this thesis shall be exploring the way in which the law, as well as the social and political implications of the time, can be seen to have impacted the victims of an attempted rape and a successful rape respectively in these representations.

\footnotetext{
57 Gunderson 2003: 70

${ }^{58}$ Roller 1997: 122 Please not that this quote has been edited, hence the brackets.

${ }^{59}$ For those disappointed by this decision and wishing to look at more of the complexities of declamatory law and Roman law may I recommend reading the works of the aforementioned Berti 2015 and Breij 2015 as well as Bernstein 2013, Ando 2011, Brescia 2015 and Meyer 2004 as a few good places to get started.
} 


\section{7: Exploring the Notion of Chastity}

Finally, when it comes to the notion of chastity it would be almost redundant to state that the Romans have always had an overly severe attitude towards it, as both a concept and practice. Livy's history of Rome, which was around the same time as the declamatory sources of Seneca the Elder with his writings being finished during the early first century C.E highlights this importance throughout his work. ${ }^{60}$ More specifically, in the first book of Livy's history, the notion of defiled chastity is explicitly stated as the inciting incident that caused Rome to evolve from a kingdom into a republic:

'Brutus, while the others were absorbed in grief, drew out the knife from Lucretia's wound and, holding it up, dripping with gore, exclaimed; "By this blood, most chaste until a prince wronged it, I swear, and I take you, gods, to witness, that I will pursue Lucius Tarquinius Superbus and his wicked wife and all his children, with sword, with fire, aye with whatsoever violence I may; and that I will suffer neither them nor any other to be king in Rome!"”

(Livy, History of Rome 1.59 [trans. Foster 1919 p.205])

Whilst the exact historical truth of Livy's history, notably his earlier histories, is open to considerable doubt and debate ${ }^{61}$ the key area of importance for this thesis is the simple fact that it was, at least at the time, held within a considerable degree of historical certainty with this inciting incident being considered an area of historical truth, and not only that but a proud area of truth. Arieti explores the way in which Livy represents rape as a foundational part of Roman

\footnotetext{
${ }^{60}$ Foster 1919: xi-xii

${ }^{61}$ See Ogilvie 1965: 22-31 for a detailed description on this topic.
} 
history with the violent act of rape being complemented with the creative act of change. ${ }^{62}$ Whilst this rape in question, and many of those explored by Livy, detail instances where it is the chastity of a woman that is threatened, these cases are still relevant to a general understanding of the way in which chastity holds an intrinsic place within Roman political and social morality.

Not only was the simple notion of chastity important but various forms of defending it, in rather extreme measures, are detailed in the writings of Valerius Maximus, dating to the reign of Tiberius 17-32 CE. The book in question, Memorable Doings and Sayings details various accounts that he gathered in order to provide one with a representative view on key topics to the Roman people. Bloomer states: 'Valerius writes of virtues made manifest in the lives of famous Romans and foreigners. ${ }^{93}$ Moreover, the writings of Valerius Maximus were designed in such a way that they were specifically of best use when being utilised by the students and practitioners of declamation as: 'Valerius' Memorable Deeds and Sayings provided a stock of rhetorical illustrations and in its treatment of this material demonstrated the various rhetorical shapes an exemplum could take and the ways to introduce, join, and conclude such stories. ${ }^{94}$

The first section of Book 6, simply titled On Chastity, details 15 accounts in which chastity was threatened, or taken, and the responses to these actions. Notably, for the purposes of this thesis, 7 of these 15 accounts detail instances in which the chastity of a man is threatened. This goes to illustrate that clearly the chastity of a man was an area of concern to the Roman people as cases detailing it appear almost as frequently as those dealing with a woman's chastity. This importance of chastity to both genders is stated by Valerius Maximus in the introduction to this

\footnotetext{
${ }^{62}$ Arieti 1997: 226. Arieti explains how this sentiment is expressed in his previous works Arieti 1980: 18

${ }^{63}$ Bloomer 1992: 23

${ }^{64}$ Bloomer 1992: 2
} 
book when he proclaims: Chastity, chief buttress of men and women alike' (Valerius Maximus Memorable Doings \& Sayings 6.1.1 [trans. Bailey 2000]) ${ }^{65}$

This further demonstrates the equal importance that chastity held in maintaining the perceived honour of both Roman men and women, whilst alluding to the fact that threats to either gender were considered to be equally common. Moreover, whilst further detailing the overall importance of chastity, and before even delving into any of the aforementioned specific cases, Valerius Maximus addresses chastity in the following way: 'By your protection the emblems of boyhood are defended, by reverence for your divinity the flower of youth remains intact, under your guardianship the matron's robe is appraised.' (Memorable Doings \& Sayings 6.1.3$1.5)$.

This simple description further demonstrates that, according to Valerius Maximus, within Roman society chastity was a key value that must be protected in all Roman citizens. The extent to which chastity can be defended is most apparent in the following instances detailed by Valerius Maximus. Firstly, there is the case of T. Veturius and P. Plotius which goes as follows:

'That was severity in the popular assembly, this in the senate house. T. Veturius, son of the Veturius who in his Consulship had been surrendered to the Samnites because of a treaty dishonourably concluded, as a very young man was forced by domestic ruin and a load of debt to give himself as bondman to P. Plotius. Plotius flogged him like a slave because he refused to submit to sexual advances and he made complaint to the Consuls. Informed of the matter by them, the senate ordered Plotius to be put in Gaol.

\footnotetext{
65 This translation, found in Bailey 2000: 3-13, is the one that shall be deployed throughout the rest of this chapter. It shall not be specified again.
} 
For it was wished that chastity be secure to Roman blood in whatever condition that might be placed.'

(Memorable Doings \& Sayings 6.41-46)

This case clearly demonstrates the way in which chastity was protected regardless of circumstance. Even though Veturius had willingly sold himself as a bondman to Plotius, thus lowering himself to essentially the position of a slave, his chastity and the protection of it was never within doubt. It is clear that the issue above arises when Plotius treats Veturius entirely like a slave ${ }^{66}$, punishing him for not following his instructions like any Roman would punish their slave. Obviously, due to the fact that Veturius, even in this significantly lower social status, is not a slave as he is still considered to be a Roman citizen a threat to his chastity is a grave offence with Plotius being given the punishment of exile. This example clearly demonstrates the notion that the protection of one's chastity, provided they were a Roman citizen, was not impacted by the highly rigid class structure of Roman society as any citizen, even those of the lowest possible social standing were entitled to the same levels of protection when it came to defending their chastity.

Not only was the protection of one's chastity never in doubt when it came to defending those of the lowest social standings from the Roman elite. But even those who attempted to violate notions of chastity whilst holding positions that afforded certain levels of social and political protection were equally open to prosecution if they attempted to violate the chastity of a Roman citizen. Valerius Maximus describes an example of this in the following way:

\footnotetext{
${ }^{66}$ Refer back to earlier discussions in this chapter on what could be done to one's slave given their lack of status.
} 
'There follows an example excellent in name and memorable in deed. Curule Aedile M. Claudius Marcellus summoned Tribune of the Plebs C. Scantinius Capitolinus to trial before the people on a charge of having tried to seduce his son. Scantinius asserted that as a holder of a sacrosanct power he could not be forced to attend and on that account asked the Tribunes for aid. But the entire board of Tribunes refused to intervene to prevent an inquiry concerning chastity from taking its course. Scantinius therefore was cited as defendant and convicted on the sole evidence of the person who had been solicited. We are told that when the young man was brought to the rostra he fixed his eyes on the ground and persistently kept mute, by which modest silence he contributed powerfully to his own avenging.'

(Memorable Doings \& Sayings 6.29-36)

This case further demonstrates the immense importance that was placed on the value of chastity and how its defence was held greater than even some of the most established traditions in Rome. Even someone with the power and status of Tribune of the Plebs a role that, as illustrated above, came with numerous political and social protections with the powers of sacrosanct was still open to attack when it came to issues surrounding chastity.

This idea of public influence not mattering when it comes to cases of chastity are further detailed in the case of war hero C. Cornelius who was charged, even after laying allegations that the man in question with whom he had had sexual relations with was a prostitute as neither his hero status nor the young man's history mattered when it came to the idea of Cornelius violating his chastity. (Memorable Doings \& Sayings 6.47-53). 
Finally, it is worth briefly addressing the case of M. Laetorius Mergus which goes as follows:

'To the punishment of a lustful Centurion succeeds the equally ignominious end of Military Tribune M. Laetorius Mergus. Tribune of the Plebs Cominius summoned him to trial before the people for having tried to seduce his adjutant. Laetorius could not bear his conscience in the matter, and before the trial date penalized himself, first by flight and then by suicide as well. He had fulfilled the limit of punishment, but after death was nonetheless convicted of unchastity by vote of the whole people. $\frac{12}{2}$ The military standards, the sacred eagles, and the severe discipline of the camp, that surest guardian of Roman empire, pursued him even to the underworld, since he had tried to become corrupter of the purity of one of whose valour he should have been preceptor.'

(Memorable Doings \& Sayings 6.54-60)

This example is noteworthy as, unlike the previously mentioned examples, it focuses less on the notion that chastity must be defended regardless of the status of the person accused or the person attacked. Instead this example explores the lengths to which the Roman people would go to ensure that chastity was officially defended. Even after M. Laetorius Mergus had committed suicide after the allegations were laid against him, the Roman people still deemed it necessary to officially convict him of this heinous offence.

All these demonstrate the seriousness of the Roman people when it came to chastity. Regardless of status (so long as the offended party was a Roman citizen of course), legal protections, social standings, or even ability to appear at a trial due to being deceased, the Roman people went out of their way time and time again in order to uphold one of their founding notions that chastity, of both male and female citizens, must be defended regardless of circumstance. This high regard for chastity is pivotal to keep in mind and understand when examining the declamatory and legal 
cases to follow which shall explore instances when this chastity is either threatened or entirely taken away. 


\section{CHAPTER TWO:}

\section{PSEUDO-QUINTILIAN'S MAJOR DECLAMATIONS 3}

\section{1: Background on Pseudo-Quintilian}

As the name Pseudo-Quintilian suggests, the authorship of the Major Declamations, a collection of 19 books detailing 17 controversiae, is a matter of debate. Originally discovered, in its entirety, by Poggio Bracciolini, an Italian scholar living from the late $14^{\text {th }}$ to mid $15^{\text {th }}$ centuries $\mathrm{CE}$, these works were falsely assumed to be the works of Quintilian. The reasoning for this largely stems back to the existing work on Quintilian at the time of these works discovery, this being the Institutio Oratoria. The Institutio Oratoria was a 12-book treatise of rhetoric focusing on the importance of the education of Romans throughout all stages of their life and Quintilian's personal views on the best way in which said education should take place. ${ }^{67}$ Notably found within this work are Quintilian's thoughts on rhetorical schools and the declamation found within:

'And since we have come to this topic, let us spend some more time on the rhetoric schools: for even here the orator is cultivated and how one pleads as an orator is entailed in the question of how one declaims'

(Quintilian Institutio Oratoria 9.2.81 [trans. Gunderson 2003 p.63])

${ }^{67}$ Gunderson 2000: 87-88 
Here it is clear that Quintilian is establishing the importance that he places upon declamation as he compares one's ultimate skill in all things oratorical to their ability to declaim. ${ }^{68}$ It is perhaps unsurprising then that, due to his affinity for and history of teaching declamation, the Major Declamations were originally prescribed as being works of Quintilian.

Over the years it has become increasingly clear that the authorship of the Major Declamations was incorrectly ascribed to Quintilian, with the reality being that this work was composed by a number of authors, maybe as many as four. ${ }^{69}$ Moreover, this work was not only prescribed to the wrong author but also incorrectly dated. Whilst the authorship of each case of the Major Declamations varies, given the fact that numerous authors worked on it, Gunderson offers the explanation that Major Declamations 3 belongs on the earlier end of this dating timeline ${ }^{70}$, even as early as the works of Quintilian himself which dated to the late first century $\mathrm{CE}^{71}$. The reasoning for this argument is firmly based in the writings of Håkanson with it being clear that the authorship of Pseudo-Quintilian's work ranges from as early as a contemporary with Quintilian to as late as the third century CE. ${ }^{72}$ This thesis readily accepts this claim surrounding the dating with the writings that shall be addressed throughout the remainder of this work having the presumption of dating around the late first century CE.

All of this is to illustrate the point that there is a clear and present distinction between the opinions and writing style of Quintilian v Pseudo-Quintilian and to say that the views of one directly reflect the other would be a dangerous realm of argument for one to enter. Ultimately, both of these authors are important to this study due to their emphasis on declamation however

\footnotetext{
${ }^{68}$ Bablitz: 186-187

${ }^{69}$ See Håkanson 1986: 2284-2294 for a summary on the scholarship on authenticity.

${ }^{70}$ Gunderson 2003: 158

${ }^{71}$ Roberts 2007: 95

${ }^{72}$ Håkanson 1986: 2284-2285
} 
this thesis wishes to clearly demonstrate, both personally and to the reader, a degree of distance between the two authors.

\section{2: The Historical Setting of Major Declamations 3}

Before analysing the specifics detailed by Pseudo-Quintilian it is worth addressing the rather obvious fact that distinguishes this piece of declamatory writing from its peers. This being that Major Declamations 3 takes place in a historical setting.

This is unique as, outlined within chapter one of this thesis, controversiae all dealt with events one step removed from historical Rome, taking place in a fictionalised society modern scholarship refers to as Sophistopolis. ${ }^{73}$ When discussing the purpose of declamation, Beard outlined it as follows:

'to construct a fictional world of "traditional tales" for negotiating, the fundamental rules of Roman society; they "naturalise the arbitrariness" of those rules by setting them in the context of legal sanction; they offer a vision of higher authority - defined not in terms of divine intervention, but in terms of the social sanction of Roman law; they provide a focus for the representation and constant resolution of central Roman/human conflicts that everyday social regulations do not (and can not) solve; they offer an arena for learning, practicing and recollecting what it is to be and think Roman. ${ }^{74}$

\footnotetext{
${ }^{73}$ Russell 1983: 21-39

${ }^{74}$ Beard: 1993: 56
} 
This line of reasoning demonstrates how declamations served a place in Roman society to allow one to apply Roman law and ideology to a setting detached from Rome itself in order to assess cases and questions situated on Roman ideology that do not directly challenge the Roman way of life. This was done whilst still providing the declaimers and audience with a scenario that allowed analysis of Roman ideology and thought. The fact that this case therefore takes place in a historical setting is clearly of great importance for a number of reasons.

Before delving into these however, it is worth explaining the historical backdrop that this controversia places itself within. The event in question took place during the Romans war against the German tribe the Cimbri. ${ }^{75}$ Dating for this event has been attributed by Sussman to $101 \mathrm{BCE}^{76}$ The specifics are that a tribune in the army of Marius, who was also his nephew, was murdered by one of his soldiers after he attempted to sexually assault that soldier. ${ }^{77}$ The soldier in question was therefore bought to trial before Marius and the whole army on the charge of murder. As detailed by Plutarch, when it came to the case: 'there were many accusers, but not a single advocate, wherefore Trebonius himself courageously took the stand and told all about the matter' (Plutarch Life of Marius 14.18-20 [trans. Warner 1958 ${ }^{78}$ ]). This fact is important to note as, when exploring Major Declamations 3, it is clearly possible that PseudoQuintilian has adopted a different angle from the historical one by placing himself as the voice of an advocate fighting on Trebonius' behalf rather than holding the historical reality that Trebonius was the one to advocate his own case.

Moreover, issues arise when addressing the fact that this event, being a historical one, has a definitive conclusion. As was explored in chapter one, a key feature of declamation was that

\footnotetext{
${ }^{75}$ Langlands 2006: 265

${ }^{76}$ Sussman 1987: 247

77 Santalangelo 2016: 44

${ }^{78}$ Warner's translation, found on pages $16-18$, is the only one that shall be utilised in this thesis.
} 
they served more as an exploratory tool than as definitive arguments with the focus being placed on practicing what one would say in a given situation rather than what the outcome of said case would be. Whilst, in the work of Major Declamations 3, no definitive outcome is stated due to the fact that controversiae did not offer outcomes, it is apparent that the outcome of this case would have been known to those present given its rather infamous status within Roman history. The outcome in question is highlighted by Plutarch as follows:

'Then Marius, filled with delight and admiration, ordered the customary crown for brave exploits to be brought, and with his own hands placed it upon the head of Trebonius, declaring that at a time which called for noble examples he had displayed most noble conduct.'

(Plutarch Life of Marius 14.21-24)

This description clearly states that Marius not only ultimately finds Trebonius in the right for acting how he did, and therefore not culpable of any punishment, but moreover celebrates Trebonius' actions as exemplary ones that all Romans should hope to achieve. ${ }^{79}$

It is worth noting that it is not only in the writings of Plutarch that this case can be found. Cicero makes mention to it in both his De Inventione 2.124 and Pro Milone 9. Moreover, Valerius Maximus' Memorable Doings and Sayings 6.1.12 attests to the same historical setting. Finally, even Quintilian aforementioned Institutio 3.11.14 makes mention of this historical case. All of these instances demonstrate that this case had an enduring place within Roman oratory. ${ }^{80}$

\footnotetext{
${ }^{79}$ Gunderson 2003: 158-159

${ }^{80}$ Langlands 2006: 265
} 
All of this backdrop is important to keep in mind as it provides an inherent bias to the ideals and opinions expressed by the advocate in Major Declamations 3 as this advocate, taking the side of Trebonius in his argument, has the inherent bias of historical hindsight to support his claims. Langlands affirms this view when she states: 'the historical setting, to which the text draws attention, works in a number of ways to lend this case particular resonance, tying its events into an exemplary framework that links past, present and future in a casual chain. ${ }^{, 81}$

\section{3: Breakdown of the Source}

Now that an understanding the historical context has been explored, it is finally time to delve into the controversia itself:

'During the Cimbrian War a military tribune attempted to sexually assault one of Marius' soldiers. The soldier killed the tribune, a. kinsman of Marius. He is accused of murder before the general.'

(Pseudo-Quintilian Major Declamations 3 [trans. Gunderson 2003]) $)^{82}$

As we have discovered within Plutarch's writings, the name of the soldier in this case is Trebonius. Moreover, the historical setting allows one to discern the name of the tribune, this

\footnotetext{
${ }^{81}$ Langlands 2006: 267

${ }^{82}$ Gunderson's translation, pp. 240-253, shall be the only one utilised for the rest of this thesis. This will not be stated again. For those curious, Sussman's 1987 translation is also an excellent one that Gunderson himself offers one to read. However, as much of this thesis' work leans heavily on Gunderson it is only logical that his translation would be the most appropriate.
} 
being Lusius. ${ }^{83}$ Going forward this thesis shall be adopting these names when referring to these figures.

When introducing his translation, Gunderson offers a few words of advice for those who wish to analyse declamation: 'One is encouraged to read things into this speech, and plenty of the sexual content is offered via insinuation. The logical flow of the ideas can be surprising. ${ }^{84}$ These words of advice are useful in justifying the levels of in-depth analysis that this thesis shall deploy, both when examining Major Declamations 3 and Controversiae 5.6. Moreover, Gunderson's claim about the flow of the speech is indeed accurate and in order to salvage this for the sake of reading ease a couple of steps have been taken. The first of these is that this section of the thesis shall offer a brief summary of the work in order to orientate the reader to the overall feel of the declamation. Following this, each remaining section in chapter two shall explore a particular theme found within the controversia with aspects from the overall work being incorporated when analysing said theme. These themes in question shall be: 1) the representation of Lusius, 2) the representation of Trebonius, 3) the importance of chastity and 4) the implications of the military setting.

The first section of this controversia begins with the advocate stating how the actions of Lusius have negatively impacted the entire military camp and his personal reputation forever. Moreover, the advocate raises the point that Lusius' actions are a clear symptom of the current decadent and declining age that they live in. (3.1) Moving on, a series of points surrounding the actions of Trebonius are addressed with it being established that he only acted in such a way as it was his chastity that was under attack and that, no matter what the outcome was,

\footnotetext{
${ }^{83}$ Warner 1958: 17

${ }^{84}$ Gunderson 2003: 241
} 
Trebonius would hold no regret for these actions. (3.2) A hypothetical scenario is then raised centred around what message punishing Trebonius would send and how this action would result in a world where anyone could pick out soldiers from the Roman legions for their own sexual pleasure. (3.3) The advocate then illustrates how it is the purpose of the Roman military to stave off ruin and strife, with particular emphasis being placed on how honourable this purpose is. (3.4) Following this, a direct appeal to Marius' honour and status is given with focus being centred on how parents willingly send their children off to fight under his leadership and the advocate explicitly stating how Marius goes out of his way to show care as a commander. (3.5) In a direct contradiction to the section before, the advocate then attacks the leadership and character of Marius by stating how he neglected to see the true nature of Lusius behind the military mask that he presented to the world. (3.6) In the next section, it is granted that Trebonius' accusers are correct in stating that he killed Lusius. However, this action was actually courageous and notably performed with the same weapon that Marius gave Trebonius for the purpose of defending the chastity of Roman women and children. (3.7) Recounting Trebonius' own words, the advocate states how he not only does not regret killing Lusius but wishes he could do so repeatedly. Additionally, the advocate raises the fact that Trebonius' actions were the more honourable than the alternative of reporting this offence after allowing it to happen. (3.8) At the midpoint of this controversia, the advocate flips the script by asking Marius a series of rhetorical questions centred around what he would have done if he were in Trebonius' place. (3.9)

Continuing the attack on Marius, it is argued that any decision Marius makes shall be influenced by his own self-interests rather than acting purely on what is right. ${ }^{85}$ (3.10) The

\footnotetext{
${ }^{85}$ Interestingly this claim does hold some historical ground as Plutarch remarks that news of Marius' decision to not only drop the charges against Trebonius but actually praise him for his actions: 'were brought to Rome and helped in no small degree to secure for Marius his third consulship (Plutarch Life of Marius 14.25-26)
} 
advocate then draws upon the history of the importance of chastity in Rome with particular stories being mentioned to support his claims. (3.11) Another exaggerated hypothetical is raised when the advocate muses why prostitutes are not allowed in Roman military camps. The answer to this could be that they may not be needed, as men such as Lusius can simply indulge in their base desires already with the soldiers at hand. (3.12) The advocate then swiftly provides Marius with another rhetorical question. This one stemming back to the idea of whom he would rather have fighting in his army during this time of war, the options being soldiers like Lusius or those more akin to Trebonius. (3.13) Exploring an imagined world where Lusius was alive, it is addressed how Trebonius would not be on trial in this case and all current outrage would instead be directed towards Lusius for his actions of sexual misconduct. (3.14) Appealing once again to Marius directly, the advocate states that this trial is actually yet another chance for Marius to pass yet another noble verdict. (3.15) An exploration of the complexities of this incident are then explored when the advocate raises the point that even if Trebonius had simply said no to Lusius he still would have been liable to trial for disobeying the direct orders of his superior officer. (3.16) Further discussion of actions done in the name of chastity are then brought up, with particular attention being placed on the fact that Trebonius is a common soldier (3.17) In his final direct appeal to Marius, the advocate addresses the nature of the familial relationship between Marius and Lusius. It is then argued that this relationship should no longer matter as Marius should simply disown this familial connection on account of Lusius' last actions in life. (3.18) Finally, the advocate concludes his speech by reaffirming Trebonius' innocence and arguing that, even if he is judged guilty, Marius should at least utilise his death by sending him back out to battle. (3.19) 
When reading through the following four sections, one may notice that certain areas of the controversia are being omitted from analysis. ${ }^{86}$ The reasoning for this is simple. The sections being omitted, whilst interesting in their own right, have nothing to directly tie them to the overall area of focus that this thesis is addressing. These sections ultimately deal more with direct appeals to Marius and overall allusions to his greatness then any interesting discussion of the nuances of the attempted rape and the following discussion surrounding its implications.

\section{4: The Representation of Lusius}

The first area of exploration is the way in which Pseudo-Quintilian presents the character of Lusius. The controversia provided in the voice of an advocate, who is identified as a fellow solider of Trebonius ${ }^{87}$, begins by outlining the impacts that Lusius' actions have had:

'The camps were sufficiently shamed and soiled when this idea overtook the mad tribune: he thought that in the middle of the din of Cimbrian war in front of the standards - you will pardon me for what you are about to hear - he would bid a man girt with his sword to stand forth, and then he would try to apply foul and criminal violence to - lest I say anything else - a man braver than himself.'

(Major Declamations 3.1)

Perhaps more striking then anything that is being said in this opening statement is what is, rather clearly and pointedly, remaining unsaid. The advocate dares not mention the specifics of what was attempted, this being a rape, instead preferring to refer to it as an act of criminal

\footnotetext{
${ }^{86}$ Specifically, Major Declamations 3.4, 3.5, 3.13, 3.14, 3.15 and 3.18.

${ }^{87}$ Gunderson 2003: 242
} 
violence. As was earlier identified by Gunderson, this is not uncommon within this controversia as the sexual content is offered by way of insinuation. ${ }^{88}$ As argued earlier, the purpose of declamation was to enable the Romans to discuss topics removed from their society with Langlands specifically applying this sentiment to Major Declamations 3 when she stated: 'The topic drives a wedge into one of the key issues found in our sources: how should one deal with the situation where someone attempts to inflict stuprum upon someone else? ${ }^{89}$

In a direct response to this point, the advocate makes it abundantly clear that the perpetrator of such an attempted stuprum is to be negatively impacted for their actions. In this case this results in a shame that extends not only to Lusius but to all those present in his immediate area of interaction. This sentimentality is further explored when, in the same section of the controversia, the advocate states: 'An eternal stain besmirches him, and news of this novel crime has made the rounds until it has become an exemplary case after which vice sets off in ready and eager pursuit.' (Major Declamations 3.1)

This eternal stain in question is a clear reference to the attempted rape of Trebonius, an action that was seen as so horrific within the eyes of the Roman people that, regardless of any heroic or honourable actions that the Tribune may have performed throughout his life this single action shall now dictate the way in which he is remembered.$^{90}$ This eternal stain is all the more relevant and poignant due to the fact that little to nothing else is known about the Tribune in question and therefore it is rather clear that his legacy is simply his final horrific action. ${ }^{91}$

\footnotetext{
${ }^{88}$ Gunderson 2003: 241

${ }^{89}$ Langlands 2006: 265

${ }^{90}$ Langlands 2006: 269

${ }^{91}$ Obviously, this enteral stain is relatively self-fulling to include as this controversiae was created centuries after the event in question, so Pseudo-Quintilian was already well aware of the way in which this Tribune was being remembered.
} 
The final statement to be explored when analysing the representation of Lusius within Major Declamations 3 is centred around the advocate attempting to discern what caused Lusius to become infatuated with Trebonius to such an extreme degree that he would go about attempting to perform this sexual violation:

'What attracted him? The way the soldier ran in the forefront before the standards; the way a raw recruit outstripped veterans; the way he came back caked with dust and blood. It was this, the very fact that he was such a man. Beauty and youth are vulgar enticements: there's nothing like sleeping with a brave soldier.'

(Major Declamations 3.6)

When exploring this section, Langlands pays direct attention to how the advocate ensures that: 'what is dwelt upon is the tribune's extraordinary and disturbing desire to have sex with a soldier, who should never, under normal circumstances, be considered sexually attractive at all. ${ }^{92}$ Even when exploring the character of Lusius through a lense that would normally incite a semblance of sympathy or understanding, the primary focus is focused upon how his actions and justification for these actions are perverse and wrong. The advocate is ensuring that the reader at no point identifies with or even understands the character of Lusius as any sort of sympathy would undermine their central arguments as to why it was not only necessary but right that Lusius was murdered. The first way to understanding this point of view is to ensure that the reader has no semblance of pity towards the fate that Lusius has succumb with the advocate ensuring this by detailing Lusius in the worse possible light. This notion is furthered by the representation of Lusius' lack of masculine self-control throughout the controversia.

92 Langlands 2006: 270 


\section{5: The Representation of Trebonius}

Based upon this understanding of the advocate's motives it is perhaps unsurprising that the first time Trebonius is bought up within the controversia it is as part of an explanation as to why he decided to respond to Trebonius' threat with murder: 'In all honesty, Marius, he would not have fought back so vigorously if the tribune had wanted to kill him.' (Major Declamations 3.2)

This image of Trebonius immediately brings to mind a paragon of justice who acts solely based upon what is the best course of action from a moral standing. This comes about due to the fact that Trebonius holds his own life in less regard than his chastity. In fact, this representation of Trebonius is not dissimilar from those offered by the other primary sources that reference him. As Gunderson noted, Cicero was unambiguously pleased with Trebonius ${ }^{93}$ even stating: 'The good youth preferred a hazardous act to a vile suffering.' (Cicero Pro Milone 9 [trans. Gunderson 2003 p.158]) Additionally, as was explored in the historical setting section of this chapter, Plutarch presents Trebonius as being so impressive that Marius crowned Trebonius as though he had just acted in some grand military exploit and illustrates that he should serve as an example to all. (Plutarch Life of Marius 14.21-24) All of this is to say that PseudoQuintilian's first mention of Trebonius serves to highlight this idealised version of his character that is preserved across sources. This is an unsurprising revelation as Pseudo-Quintilian, taking the role of the advocate arguing for Trebonius, would obviously wish to portray Trebonius in a positive light in order to justify his action of murder.

\footnotetext{
${ }^{93}$ Gunderson 2003: 158
} 
This heroic portrayal of Trebonius is immediately followed by the advocate lamenting the possibility of Trebonius losing this trial: 'If this is what fortune brings him, then he will go to his punishment in full stride, as ready to die as to kill in the name of chastity' (Major Declamations 3.2) In her analysis of Major Declamations 3, Langlands makes it apparent that Pseudo-Quintilian needs to establish the fact that:

'A defence of the soldier must place the highest premium upon pudicitia, in order that it may be called upon to justify the murder of one's military superior. Thus, in the rhetoric of Ps. Quint. Decl. 3, succumbing to stuprum is represented as a worse fate than death, and by the same token pudicitia is more important than life itself.' 94

When it comes to defining pudicitia the most simplistic translation is to the term sexual virtue. ${ }^{95}$ By demonstrating a lack of regret for Trebonius' actions the advocate is clearly attempting to persuade the audience, and namely Marius, that his actions were in the right and guilt is merely a feeling of the guilty or unsure. Moreover, when stating that Trebonius is willing, and almost happy, to die in the name of chastity the advocate is making clear allusions to other honourable Romans that have died in the name of chastity, either to protect it or to martyr themselves after it has been violated. Such cases shall be explored later in this thesis when I discuss the controversia, with a section of this chapter dedicated to these cases, however it is at this moment that the seeds are planted in the mind of the audience. ${ }^{96}$

\footnotetext{
${ }^{94}$ Langlands 2006: 269

95 See Langlands 2006: 2-3 for this translation and an extensive exploration of the complexities of this term.

96 These seeds would have been easily picked up upon both to the imagined contemporary audience, that being the well-educated Marius, and the modern audience of the controversiae when it was constructed as everyone who witnessed it would have been well-educated elite. Therefore, the advocate is cleverly using this historical scenario to their advantage to be able to speak in terms that any educated Roman would have understood without it creating tonal dissonance with the scenario that the controversiae is placed.
} 
Moving on, the advocate then brings into question an intriguing idea for this thesis as a whole, this being the way in which this attempted assault has affected the character of Trebonius: 'But for my part - and please believe me - I blush even to praise chastity in a solider: this virtue is an attribute of women.' (Major Declamations 3.3)

This remark brings into focus the way in which Trebonius' masculine identity has been impacted by this attempted assault. As explored by Langlands: 'To be sexually attracted to another male is to deny his manhood, to treat him as child, a pretty boy. ${ }^{, 97}$ This change is apparent as the advocate is clearly questioning why he would even need to praise Trebonius for his chastity. The answer to this question leading back to the fact that Trebonius' chastity was put into a position where it was threated, with this threat resulting in the transformation from Trebonius the soldier to Trebonius the victim comparable to the members of Roman society who are worthy of praises on account of their chastity.

The notion of Trebonius' manhood being negatively impacted is further explored by Langlands:

'just as the tribune, by inflicting sexual advances on the soldier, has undermined the latter's manhood, so the speaker too is casting aspersions on the soldier's manhood by working with the necessary assumption that the soldier is vulnerable to the other's stuprum. Here adducing the concept of pudicitia destabilises boundaries that need to be clearly drawn between males of different status. ${ }^{98}$

\footnotetext{
${ }^{97}$ Langlands 2006: 270

${ }^{98}$ Langlands 2006: 270
} 
Two points accordingly come into focus. The first is that the manhood of Trebonius has been brought into question due to the fact that his chastity now needs to be praised as he was put into a situation where it was threatened. The second is that, through defending Trebonius, the advocate is further damaging his masculinity as he is needing to compose a narrative where Trebonius' chastity was under such a strong threat that swiftly murdering the assailant was the only viable option. This fact therefore implies that Trebonius was essentially powerless in the fact of Lusius' assault and would have been overpowered without the use of his sword. Ultimately, by needing to praise Trebonius' chastity, the advocate is bringing into question his manhood with this negatively impacting the way in which Trebonius would have been viewed, as he is no longer the ideal male citizen.

Perhaps as a direct response to the negative implications that the advocate has placed upon Trebonius' character, a defence of why Trebonius acted the way he did proceeds as follows:

'I don't deny the charge: no, even if the accusers sat there in silence, I would have recounted the story myself. So reproach him, but do it as it befits informers: tell the whole story. It's less shameful for a perfectly chaste soldier to make a confession than to lodge a complaint in earshot of our most saintly general.'

(Major Declamations 3.8)

With the previously established context of Trebonius' manhood being impacted by both the attempted rape and the words of the advocate this statement serves to offer consolation. Whilst there is nothing that can be done to repair the damages to Trebonius' manhood, here the advocate is illustrating that the current outcome for Trebonius is the best possible one he could have experienced. Whilst his manhood was threatened his chastity was never violated and 
therefore his manhood whilst damaged is not beyond repair. Additionally, this case speaks to the complications of the military setting with this not only being the best course of action for Trebonius from the perspective of his manhood but also in relation to the actions he could have taken in response to a threat from his direct superior.

Finally, the advocate concludes his defence of Trebonius by further attesting to the heroic representation of him established earlier:

'I am positive that you are not waiting for a conclusion to my speech where with wretched tears and humble supplication the soldier begs for his life on bended knee. You don't have to demand entreaty from an innocent man; nor does a hero have need of a forgiveness that he had to beg for. He asks only one thing, that if you have the least doubt about his case, that you put things off until the next battle, put him in the front line, put him before the standards. My words may be bold, but don't put him amid the raw recruits, put him where there is the most danger, where the enemy throngs make their fiercest attack. Watch him fighting. I declare that then you will have fewer excuses for the tribune. Let him go into the battle-lines, let him draw near the enemy. If he ought to die, general, your soldier asks that you make use of his death.'

(Major Declamations 3.19)

These final remarks clearly and concisely detail the major aspects of the advocates argument. He restates that there is no need to plead for Trebonius, as he is a hero who has no need for such actions. The impeccable character of Trebonius is further stated when it is said that even if he were to be charged and put to death then at least let his death be of some benefit to the 
Roman people, echoing how his actions in life have been equally of importance as they have helped to uphold the ever important value of chastity.

Overall, the representation of Trebonius within this controversia is a complicated one. The advocate spends the majority of his time attempting to portray Trebonius in an idealised light in order to further justify his actions and present an excellent parallel to the villainous portrayal of Lusius. However, even when attempting this, the advocate cannot help but demonstrate the vulnerability of Trebonius' masculinity as a result of this threat of rape and the way in which he is now being addressed because of this. Ultimately, through analysing Major Declamations 3 one gleans a picture of an idealised hero who has nevertheless had his image and status negatively impacted by the actions that he was threatened with.

\section{6: The Importance of Chastity}

Moving on to the way in which chastity is explored within this controversia, when describing the event as it happened the advocate raises the following point: 'At the very first mention of perverted lust it was just as if the trumpet had sounded the charge against the enemy: he drove that sword which he had received from you for protecting the chastity of our wives straight through the breast of that unspeakable seducer.' (Major Declamations 3.7)

This description clearly ties directly into notions of chastity as the sword that is used to murder Lusius is stated as being given to Trebonius with the express purpose of defending chastity. Whilst there are some complications due to the fact that this sword was given for the purpose of defending the chastity of women. This recalls the earlier discussion on the way in which Trebonius' manhood has been impacted. It is clear that the chief purpose of this weapon being 
tied to the protection of chastity is of great importance. When exploring such notions Langlands states that: 'A man must carefully guard his own physical integrity and his reputation...this means that he must not submit to the lusts of another man. ${ }^{99}$ More specifically, when it comes to soldiers it is illustrated that their primary purpose is to defend chastity with Lusius' actions being peculiarly terrible as he is instead depicted as attacking chastity. ${ }^{100}$ By contrast, Trebonius is seen in a positive light as he is defending his chastity even in the face of military protocol, in this case by disobeying the orders of his tribune.

Moving on, the importance of chastity is then clearly stated by the advocate as he recounts the infamous founding story of the rape of Lucretia:

'What next? Am I going to tell you how chastity was ever the chief concern of Roman morality? Will I recount the story of Lucretia, she who plunged the dagger into her own breast and exacted punishment on herself for an act forced upon her, Lucretia who sought to sunder her unchaste spirit from her soiled body as swiftly as she could as so stabbed herself because she could not kill her ravisher?'

(Major Declamations 3.11)

The tone with which the advocate addresses this story demonstrating the fact, already established in chapter one, that this tale was a well-known and highly regarded by the Roman people. ${ }^{101}$. Here the advocate is utilising what is referred to as preterition, the act of mentioning something by professing to omit it. In this instance the advocate is questioning whether he even needs to address the place that chastity held within Rome or the tale of Lucretia. By stating that

\footnotetext{
${ }^{99}$ Langlands 2006: 120

100 Langlands 2006: 271

101 Arieti 1997: 226
} 
he is stating by omission that both of these are things that the viewer ${ }^{102}$ would be well aware of. All of this is to say that the advocate is using this section to remind the viewer of the importance that chastity holds within this society. This is necessary so that the advocate may justify the murder of Lusius for, as was explored by Langlands ${ }^{103}$, it is this notion of chastity being more important than life that is pivotal to the advocates argument as to why the actions of Trebonius were morally and socially right as he was upholding the highest tenet of society.

The final point directed at the importance of chastity appears near the end of the advocates speech:

'Aren't we all aware, commander, of the magnitude of the revolt that once was kindled among the Roman people when a debt-bondsman once burst forth from the house of his creditor and showed the public a back that had been shredded by beatings? He complained that he bore those marks from being punished because he was unwilling to put up with a sexual assault. And that assailant at least showed himself somewhat mindful of Roman sanctity even if he attempted this outrage against a debt-bondsman a man who could only barely be called free: he had not tried to use his utterly depraved violence until he first made sure that his victim's hands were tied. Still, the Roman people so proved itself the champion of the man that nobody would answer when a draft was called as war raged on Rome's borders until reparations were made by punishing the assailant and by the repeal of the law of debt-bondage. They were unwilling to serve even thought it was no soldier to whom this injury was done. Need

\footnotetext{
${ }^{102}$ The viewer in this case refers to both the historical Marius whom the advocate directly appeals to over the course of the controversia and the audience gathered to witness Pseudo-Quintilian's performance.

${ }^{103}$ Langlands 2006: 269
} 
I mention Fabius Eburnus, the man who killed his unchaste son after trying him at home?

(Major Declamations 3.17)

Both of these cases again deal with the idea of preterition with the advocate presenting both of them 'Aren't we all aware' and 'Need I mention' respectively. The first case mentioned is actually one that the reader will already be familiar with as it is the case detailed within Valerius Maximus' Memorable Doings \& Sayings 6.41-46 which was explored in chapter one. The only new area of information worth mentioning in this case is that it further emphasises this idea that the primary role of a soldier was the protection of chastity with the soldiers refusing to fight until the threat to this bondsman's chastity was properly addressed. The second case furthers this discussion on the overall importance of chastity by illustrating just how far the Roman people are willing to go in the name of chastity.

Ultimately, the advocate is able to use the historical setting of the controversia to incorporate historical examples highlighting the importance of chastity into his argument. This is done to further highlight the righteous intent behind Trebonius' actions and serve to exonerate him for the crime with which he is being charged.

\section{7: The Implications of the Military Setting}

The final area to address is the implications of the military setting. The purpose of this section is to explore instances where the advocate addresses the military setting and to pay particular attention to the complications that this setting holds. 
To begin with, rather common argumentative tactic still used to this day in cases surrounding moral issues, this being the idea of fearmongering and extreme cause and effect-based logic. This occurs when the advocate, whilst arguing about what the ramifications of a guilty verdict for Trebonius could be, states: 'Look at what we are really dealing with here: will one be allowed according to your own decree to pick out whores from among the ranks of the Roman legions and to haul off to illicit sexual encounters men who have been sworn to military service?' (Major Declamations 3.3)

It is fair to state that, even if Marius had found Trebonius guilty, the Roman armies would not have fallen to such debaucherous extremes. However, such extreme arguments are commonplace in any argument surrounding moral conservatism. The conservatism in this place being the aforementioned importance of chastity as a moral virtue. This arguably all stems back notion of nostalgia within the Roman mindset. This nostalgia in question relating to the notion of mos maiorum. Whilst the full implications of mos maiorum shall be explored in chapter three analysis of Controversiae 5.6 for now it is just worth noting that this value was steeped in ideals of how the modern generation had lost its way and should base their decisions on the standard set by their ancestors, these being actions that were deemed right, traditional and good. ${ }^{104}$ Bringing it back the military setting, through this example the advocate is exploring a hypothetical world where the morals of the army, the defenders of chastity, are warped thus resulting in a world where no soldiers chastity is safe.

Moving on, the advocate reaches his first point specifically detailed on the complexity of Trebonius' situation due to his military status. To do this, the advocate illustrates a hypothetical turn of events if Trebonius had taken the other path presented and allowed the defilement of

${ }^{104}$ Kenty 2016: 429 
his chastity to take place only to go through the appropriate channels to seek some sort of retribution: 'And so I suppose he should wait until dawn in order to lodge a complaint with the proper authority: his tribune!' (Major Declamations 3.9)

This fact illustrates the, for want of a better term, no-win situation that Trebonius had found himself in. Even if he had refrained from murdering Lusius in order to defend his chastity there would have been no effective means of reporting this violation as the person he should be reporting such instances to is Lusius himself. The further implications of this shall be explored in chapter four of this thesis as it ties neatly into the notion of modern parallels. For the time being, the primary takeaway from this section is to note how the advocate is aware of the complexities that Trebonius location, and his status in this location, affect his possible means of action against the threat to his chastity.

Elaborating upon the fact that Lusius was the direct superior of Trebonius, the advocate goes on to offer another hypothetical alternative to what happened by examining what Trebonius could have gained if he had allowed the rape to happen: 'And so, to take things a step further, one can even hope that he will perhaps get a promotion for this good service of his, he will lead companies, and others will serve under him.’ (Major Declamations 3.9)

Through this hypothetical the advocate is both demonstrating the complex situation laid before him and affirming the character of Trebonius. By stating such a hypothetical, the advocate is arguably hinting at cases where such actions were taken. This would involve soldiers who were morally weaker than Trebonius agreeing to this violation in order to serve their own selfish endeavours and motivations. This implication hints at the notion of instances of sexual misconduct being more prevalent than reported within literary works. Of chief importance, 
however, is the fact that this hypothetical again stems back to the fact that Trebonius is operation in a military location where he is of the lowest rank and expected to obey the order of his direct superiors.

Following this, the advocate moves on to yet another exaggerated hypothetical that is utilised to explain the military protocols surrounding women in camps: 'Is this why prostitutes are kept away from the army and it is forbidden for women to enter the camp? I guess that there is no need for them.' (Major Declamations 3.12)

This point is almost a direct attack on the character of Marius, insinuating not only an awareness but a deliberate course of action that has resulted from his awareness of the perverse desires of those around him. Of primary importance for this thesis however is not the attack on Marius' character but instead what this statement implies. In a similar fashion to the two quotes from 3.9, this statement causes the mind to race with the possibilities of what it implies. It would be unwise to take this collection of quotes and hastily jump to any conclusions surrounding the degree to which cases like this did take place, at least at this point in the thesis' analysis, however it is again another reminder of the fact that the advocate is, obviously to an extreme degree in order to elicit the desired reaction from his audience, pointing to a series of possibilities of male sexual coercions that may be occurring on a rather common basis.

Finally, the early established complications of this case due to the status of Lusius are again addressed: "When you use the word "tribune" you mean a man whom a common soldier is legally obligated to obey, a man who is put in charge of not just soldiers, but centurions as well, a man who shares some measure of the general's own power.'(Major Declamations 3.16) 
Here the advocate is clearly emphasising a simple fact, Trebonius was under a legal obligation to obey the orders of Lusius. This fact has, throughout the entire declamation never been in doubt, nor has the fact that Trebonius murdered his direct superior after disobeying a direct order. Instead the focus of the advocate's arguments has been centred around the notion that Lusius' order was perverse and improper. In fact, the advocate is bringing up this very point in order to illustrate the complications of this situation. This being that a tribune can attempt to force himself onto one of his soldiers and if the soldier does not allow this assault, then they are behaving in an illegal manner.

All of this is to state that the advocate demonstrates a clear awareness of the complexities of this cases' military setting. Instead of shying aware from these complexities however, the advocate uses them to his advantage in order to make a series of points that further highlight the perverse actions of Lusius, in direct contrast with the moral actions of Trebonius. Furthermore, this setting is utilised to the extreme in order to make extravagant points about the dangerous ramifications that punishing Trebonius for his actions could case.

\section{8: Final Thoughts}

In summation the advocates argument in this controversia centres around four main themes: 1) the representation of Lusius, 2) the representation of Trebonius, 3) the importance of chastity and 4) the implications of the military setting. By examining this controversia, one can begin to glean an interesting portrayal of Roman values and ideologies in the face of a perverse, complex and relatively unknown, or at least underexplored, threat to values of chastity, this being the potential threat to the chastity of a male Roman citizen. 
Overall, this chapter has, established the simple fact that the mere possibility of a man being sexually assaulted was a cause of great concern and could have direct impacts on the way in which their manhood is both perceived and illustrated. This sets the stage nicely for the next chapter that shall explore a case that not only deals with the idea of a male rape but explores the consequences of when this crime is actually committed, to an extreme degree. 


\section{CHAPTER THREE:}

\section{SENECA THE ELDER'S CONTROVERSIAE 5.6}

\section{1: Background on Seneca the Elder}

In a direct contrast to the issues of authorship surrounding Major Declamations, the authorship of the Controversiae is far simpler as it is clearly a work composed by Seneca the Elder ${ }^{105}$. Born in Spain around 50 BCE, the elder Seneca moved in out and of Rome throughout his life, likely studying rhetoric within Rome itself. ${ }^{106}$ It is apparent that the elder Seneca ultimately settled in the city of Rome, with this move happening sometime after the birth of his third son around 5 CE. ${ }^{107}$ These three children, Annaeus Novatus, Seneca the Younger and Annaeus Mela are instrumental in the creation of Seneca's Controversiae with its writing occurring shortly after the death of Emperor Tiberius in 37 CE. ${ }^{108}$

The primary reason why Seneca composed this work was as a direct response to a request from his sons asking that he provide them with a recollection of the words of his contemporary declaimers whilst also providing his own opinion on said works. ${ }^{109}$ Seneca himself outlines this background when he states:

'What you ask is something I find agreeable rather than easy. You tell me to give you my opinion of the declaimers who have been my contemporaries, and to put together

\footnotetext{
105 Griffin 1972: 6-8

106 Roberts 2007:

${ }^{107}$ Bablitz 2007: 2-3

108 Winterbottom 1974: xx

${ }^{109}$ Griffith 1972: 11
} 
such of their sayings as I haven't yet forgotten, so that, even though you were not acquainted with them, you may still form your own judgement on them without merely trusting hearsay.'

(Seneca the Elder, Controversiae 1.1 [trans. Winterbottom 1974]) $)^{110}$

As if evidenced by this quote, the elder Seneca constructed this work in such a way as to allow his sons to pass judgement upon each of the works contained within. In her writings Sussman assesses this claim and comes to the conclusion that this is the reason Seneca the Elder composed his Controversiae. ${ }^{111}$ When exploring this origin, Gunderson cleverly raises the question of whether an audience beyond his children was ever Seneca's intention. ${ }^{12}$ This is to ask whether the elder Seneca envisioned a life for his work that extended beyond the scrutiny on his own children. Ultimately, this question, at least in the eyes of Gunderson, appears to be irrelevant as it is far too speculative a question to effectively answer, a sentiment that this thesis readily agrees with. However, rather than just leave the reader on this unsatisfactory note, Gunderson counsels us to understand that any reader of Seneca the Elder's Controversiae become, to some extent, his son, more specifically a son with the desire to pass judgement on the world of their father. ${ }^{113}$ This is to say that, through analysing the writings of the elder Seneca's Controversiae, one is performing the same role that the intended audience for this piece, Seneca's sons, is. When one critiques and analyses the declamatory cases found within, they are passing direct judgement onto the opinions and attitudes of Seneca's generation of declaimers.

\footnotetext{
${ }^{110}$ For the duration of this thesis, Winterbottom's translation shall be the one being utilised. His book 1.1 translation is found on p. 3 and his book 5.6 translation spans pp. 489-491.

${ }^{111}$ Sussman 1978: 53-54

112 Gunderson 2003: 32

113 Gunderson 2003: 3
} 


\section{2: Seneca the Elder's Writing Style}

All of this resulted in a collection of ten books (five of which survive in near intact condition) each detailing a number of declamation cases (between six to nine depending on the book) dealing with a wide array of topics. The extent of this range can be simply illustrated by looking at the controversiae that shall be explored in this thesis: 'The Man who was Raped in Woman's Clothes' (Controversiae 5.6) and the controversiae that come on either side of it. The first of these being a case deals with issues of property damage entitled: 'The Burning of the House and the Tree' (Controversiae 5.5) and the latter being: 'The Men the General Would Not Let In' (Controversiae 5.7) which was a case centred around military protocols. Other topics of the controversia found within the elder Seneca's work are centred around issues of inheritance (Controversiae 1.1), torture (Controversiae 2.5) body mutilation (Controversiae 3.1) and tyrannicide (Controversiae 4.7). This additional list, essentially taken at random, helps to further illustrate just how wide a variety of topics these controversia covered with this range being seen both within and between books.

In contrast to the detailed speeches provided by Pseudo-Quintilian's various declamations, these controversiae are composed in the following way. First of all, there is a preface written by the elder Seneca in his own person with a series of messages to his sons, and by association the reader. Each book in turn covers between six to nine declamatory cases. These cases contain the following elements as outlined by Bablitz:

'First, Seneca states the law central to the case, followed by a brief description of the case's theme. Next he records portions of various speaker's speeches (first those for one side, then those for the other) when they spoke on this controversia... Following 
this section, Seneca provides each declaimer's "divisions", the statements that set out the main points on which the speech will be built... In the final section he lays out a section of the declaimers' various colores, their "colours" or lines of argument for the case. ${ }^{114}$

It is worth stating that the these controversiae read as far more fragmented than the declamation cases offered by Pseudo-Quintilian. This is due to the fact that the controversiae are the amalgamation of the elder Seneca's contemporaries and therefore he is merely taking down the key points that they made on either side of a given subject. Therefore, largely speaking, each sentence in the controversiae presents a new point and idea with it being fair to attribute this to the fact that these sentences and ideas were presented by a different speaker rather than the work pertaining to the unified speech and opinions of a single declaimer.

Unfortunately, this description does not entirely apply to the controversia that is to be examined, Controversiae 5.6, as book 5 of the controversiae is one of the books that has not remained intact. ${ }^{115}$ The elements that do remain for this controversia in particular are Seneca's stating of the law central to this case ${ }^{116}$. Following this, the controversia only offers the portions of the speakers who spoke on both sides of this controversia. Whilst this does leave the majority of this controversia available to the modern reader it is worth noting the absence of both the preface ${ }^{117}$ at the beginning of the book as well as the "division" offered by Seneca in sua persona. Both of these certainly remove Seneca's personal view of this case from the

\footnotetext{
114 Bablitz 2007: 3

115 See Sussman 1971: 286 for further information and a list of which books as intact if curious.

${ }^{116}$ As stated in chapter 1, this thesis shall not be explicitly exploring the nuances of law found within declamation however for those curious to assess these laws, in particular the ones found within Seneca the Elder's Controversiae a few excellent places to start would be Bonner 1949: 84-132, Harries 2016: 154-156 and Berti 2015: 7-34

${ }^{117}$ For those curious on further discussions surrounding the prefaces as a source, as well as questioning of these lost prefaces please refer to Bloomer 1997: 120-129 for an excellent discussion.
} 
reader and leave controversia noticeably shorter than the other controversiae. Rather than dwell on this negative however, this thesis shall simply accept that certain aspects of this source are missing, a not uncommon difficulty to work with when dealing with the classical world, and instead focus on what is present and available. Fortunately, what does remain is truly fascinating to explore in detail with thoughts of the consequences that should come from a man being sexually assaulted.

\section{3: Breakdown of the Source}

Before diving into the particulars of the source it is worth taking a moment to pause and address the title given by Seneca the Elder to this controversia, this being 'The Man Who Was Raped in Women's Clothes' (Controversiae 5.6.1). This title is noteworthy as it clearly states that this case deals not with an attempted rape, like Pseudo-Quintilian, but instead with the aftermath of a successful rape. This is notable as Packman illustrates that: 'homosexual rape is reported as accomplished and proven only in a single case where a young man has gone out in public on a dare - in women's clothing (Controversiae 5.6)'. ${ }^{118}$ For context, out of the thirty-five cases of Latin declamation that deal with rape, only five of these address the notion of a man being under threat of rape ${ }^{119}$ Moreover, this case in particular is the only one in which the viewer can be certain that the rape took place. Clearly this fact helps distinguish this declamatory case from any other and make it immediately raise the interest of the reader as it explores something truly rare, the representation of a man after his chastity has been violated.

\footnotetext{
118 Packman 1998: 19

119 Packman 1998: 18
} 
After the title, this source begins, rather expectedly given the outline highlighted above, with a line detailing the law that shall be pertinent to this controversia: 'An unchaste man shall be barred from speaking in public.'. (Controversiae 5.6.2-3) $)^{120}$ This law directly ties into earlier concerns raised, notably with the analysis of Major Declamations 3, of the threats to one's character that being sexually assaulted would be. In this example, a man who has been violated has now had certain aspects of his rights as a male citizen taken away. This has obviously caused a negative impact on his perceived character and social standing for a multitude of reasons. The fact that this was the response given provides and interesting insight into the way in which this declamatory society viewed a man who was raped, this being that he was essentially no better than someone who was merely unchaste. Whilst, through no inherent fault of their own, this person has been sexually assaulted and therefore forcibly had their chastity taken away. Despite the way in which this occurred this society does not appear to concern itself with the particulars, as the man in person is now being treated under the same law that deals with those who willingly flaunt themselves and become unchaste. Ultimately, one is drawn into noticing the inherent unfairness that is taking place as a law that is designed to punish those who behave in a manner unbefitting of a male citizen is being used to punish someone for actions entirely out of their control. Bringing this into direct contrast with Roman society, Walters illustrates the notion that: "the sexually "active" role [was viewed] as the only appropriate one for a adult male citizen. ${ }^{\text {'121 }}$ Williams further explores this notion by defining this need to be sexually active as: "the prime directive of masculine sexual behaviour for Romans ${ }^{\prime 22}$. Both of these sources illustrate the way in which Roman society viewed masculine sexuality and help to inform the reader on why the victim in this controversia is being affected to such a negative degree, as he has behaved in a manner unbefitting a Roman male citizen.

\footnotetext{
${ }^{120}$ Bonner 1949: 105 discusses how there are directly parallels within both Greek and Roman law to this law stated by the elder Seneca.

${ }^{121}$ Walter 1997: 31 Note this quote has been slightly edited.

122 Williams 1999: 18
} 
The controversia follows on from this statement of law to then outlining the particulars of this case in question: 'A handsome youth betted he would go out in public in women's clothes. He did so, and got raped by ten youths. He accused them of violence, and had them convicted. Forbidden by the magistrate to speak to the public, he accuses the magistrate of injuring him.' (Controversiae 5.6.4-9) These details illuminate a few key facts. The first fact is that the rape occurred due to a misinterpretation of the victim as a woman because of the clothing he was wearing, and due to this misinterpretation ten youths decide to sexually assault him. The validity of this line of reasoning obviously falls away at some point when one recounts the events of the incident. Even if the reader is willing to believe that the victim had dressed as a woman to such a success that the youths legitimately believed he was one, it is apparent that at some point in the encounter the youths would have discerned that the victim was male. The latest possible time for this discovery being when the youths discovered the victims' male genitalia. Regardless of this discovery, it is clear that the ten youths in question proceeded with their assault After the fact, the victim was able to track down these ten and have them convicted for crimes of violence. ${ }^{123}$

This simple fact, coupled with the fact that at no point throughout this controversiae are the charges against the ten youths ever brought into question, does demonstrate that this fictionalised society did have some sort of accountability in place when it came to the rape of male citizens. This is an unsurprising revelation in light of the discussions surrounding the importance of and protection of chastity that have occurred throughout this thesis in both chapters one and two. When exploring the purpose of homosexual assault in declamation Gunderson offers the explanation that: 'such a case offers a view into the social logic of

${ }^{123}$ This logically would have been under the category of vis. See Riggsby 2010: 200-201 
masculine identity' ${ }^{124}$. Through this lens one can ascertain that Roman declamation examined both sides of this masculine identity. These two sides ranging from the aggressive sexuality associated with masculinity culminating in the desire to perform acts such as rape, and passive side that could become an unwilling victim of such an assault. It is through declamation where one can view both of these sides being addressed with ownership being placed on the actions leading up to such an event and the repercussions, for both parties, because of it.

In fact, the issues that shall be raised surrounding this source are focused not on how they deal with someone who violates another's' chastity but instead how the person whose chastity was violated is treated after becoming unchaste. Based upon the fact that the victim is accusing the magistrate of injury in this controversia, it is fair to state that the victim is unhappy with the resolution of this case in regard to how the law has impacted them. This is where the clear clash between the aforementioned law in question and the details of this specific case arise as this man has now become unchaste and it becomes the job of those declaiming to state whether it is through fault of his own or whether he should be allowed to speak in public once again.

\section{4: The Case Against the Victim}

The arguments begin on the side of those who believe that it was the victim's own fault that he became unchaste. Rather pointedly, of the remaining 252 words in this case, 217 of them are in support of this side of the argument. This simple fact suggests what line of reasoning Seneca, and his contemporaries, appeared to have far more to say about. The discussion of the side opposed to the victim begins with an overall recount of the actions that the victim took on the night in question, these being that: 'He put on women's clothes, made his hair look like a

${ }^{124}$ Gunderson 2003: 154 
woman's, put on the alluring eye-shadow girls use, coloured his cheeks.' (Controversiae 5.6.10-12) Whilst, to the modern reader, there does not appear to be anything particularly damming stated in this recollection of then night in question, one need only look at the way in which such actions were viewed in the classical mindset to understand how damming they truly are. As argued by Gleason, when it came to the Romans: 'a masculine identity was an achieved state. It took years of training to perfect one's public demeanour. This training involved both voice and body ${ }^{125}$. Masculinity was a practiced art that required continued practice and expertise in order to maintain ones' image within Roman society. By acting in a way directly opposing this, notably by dressing up as a woman, the victim is doing something clearly at odds with what is expected of decent Roman men.

This simple fact of the victim behaving in an unmasculine way is pivotal to what shall be addressed by the various speakers throughout this controversia. Specifically, when it comes to the notion of cross-dressing, this act would be even more inappropriate as it is not only a man stepping out of his traditional gender role, an act already viewed as wrong in the eyes of the Roman people, but stepping directly into the actions associated with the female gender and attempting to directly imitate them by way of appearance. Williams illustrates the dislike for the effeminate by first defining it as merely the opposite of masculine and then stating that: 'effeminacy was thus a disorder embodied in various symptoms' ${ }^{\prime 26}$. This is elaborated upon by Edward's quote that: 'Whatever qualities were undesirable in a male member of the Roman elite were termed "feminine". ${ }^{127}$ All of this is to illustrate just how negatively the mere action of dressing like a woman would have been viewed and thus the purely negative association that the defender is providing when stating what the victim did.

\footnotetext{
125 Gleason 1995: 159

126 Williams 2010: 137-138

127 Edwards 1993: 1092
} 
This singular point is then followed by a trio of remarks that fit together into a unified whole of ideas: 'Don't you believe it? Yet it was those who disbelieved him who lost the bet. - Perhaps this too is the result of a bet, that he should dare to speak in public though unchaste. -' (Controversiae 5.6.12-16) This series starts by questioning whether this recount of events is even the truth, thus enhancing in the viewer's mind the absurdity of this situation and, by association, how unconventional and improper the victim's actions were. Following on, the integrity of the victim's character is bought into direct question when it is mused that all of this too could be yet another bet. This pointedly shows how the victim should not be speaking on account of him now being unchaste. Bringing this into question also illustrates the severity with which such a topic is being viewed as the advocates can only muse as to why this unchaste man would be speaking. Additionally, the only immediate answer they can propose is that the victim is acting in the same fashion as what got him into this situation in the first place, that being a bet. All of this in done in order to further belittle the character of the victim and isolate him from the proper men with whom he attempts to be allowed to speak.

Moving on, one of the speakers provides arguably the most striking line in this controversia, this simply being: 'Give him girls' clothes, give him darkness-he will get raped.-' (Controversiae 5.6.16-17) These words strike hard in both their simplicity and the horrors with which this statement conjures. There is no second-guessing, questioning or probability associated with this statement, only something that is presented as a cold, hard fact. It was never in doubt whether this action would have occurred given the circumstance, no bad luck on the victim's part or any other coincidence, rather it is clear that this was the one and only logical outcome based on the situation at hand. The tone with which this statement is provided, passes a semblance of blame onto the victim as, if this outcome were as predictable as is being 
outlined here, then the victim should have been aware of this and therefore not behaved in the way that he did if he did not desire to be raped.

This brings up two key points. The first of these is the implication of an aggressive sexualisation that is found within this society, one that readily accepts and even encourages such sexual violations to occur. In his work, Packman states the idea that: 'The texts of the Latin declamations themselves establish that the society which produced them was not as reticent about rape as is our own, but frankly acknowledged such episodes as a fact of life in their own society - problematic, but by no means unmentionable.' ${ }^{128}$ Williams also expresses a similar notion when exploring the cause for homosexual desire in the ancient world: 'But none of these philosophical texts condemns, questions the naturalness of, or otherwise challenges the normality or even normativity of males' desire to penetrate other males' ${ }^{129}$. Essentially what this controversia, and both of these secondary sources, are illustrating is that there was a universal acceptance of both homosexual desire and rape in the ancient world with this resulting in a society that willingly adopts such violent acts, even against their own citizens, as a normal part of daily life. This acceptance strongly implies instances of rape occurring on a regular basis, far more than any sources will depict, a notion that shall be explored in further detail in chapter four of this thesis.

The second point to address that this assumption of events clearly ties directly into the notion of victim blaming. As was stated in chapter two, an in-depth analysis of the victim blaming found within both sources shall take place within chapter four. As a hint of what is to come, it is worth briefly stating that, according to Skaine: 'The victim is often blamed for the attack.

\footnotetext{
128 Packman 1998: 36

${ }^{129}$ Williams 2010: 263
} 
The reasons given are the victim was (1) dressed provocatively...' ${ }^{130}$. Without diving into the rest of the list of reasons for this blame, or the further ramifications of this list it is clear that there is a direct parallel between the ancient and modern idea of blame. According to the controversia, due to the way in which the victim dressed, it is his fault that he was violated and therefore became unchaste. This notion of placing blame onto the victim in this controversia is a theme that shall be seen throughout the remainder of the analysis of this source.

The next line swiftly moves back to the idea of directly questioning, and indirectly attacking, the character of the victim when one of the advocates states: 'He was so suited by the dress he put on that it looked as though it wasn't the first time he had put it on.-' (Controversiae 5.6.1719) This line, clearly being an attack centred around the fact that the victim has had some experience in dressing up as a woman causes a direct attack to his character by demonstrating that he has a history of behaving in a feminine way. This ties back into the earlier discussion of how anything that is perceived as feminine is, by association, unmasculine. ${ }^{131}$ The notion of the negative associations of any sort of feminine image are explored by Williams, specifically in reference to the Emperor Otho, when he states: 'Otho was reputed to have been overly fond of pampering himself and acquired a reputation for effeminacy: Juvenal pillories him for a womanish primping that surpassed that of Semiramis or Cleopatra; Suetonius reports that on the day he was hailed as emperor he was traveling in a woman's sedan, and that he was fond of adorning himself in an effeminate manner, even depilating his body; and Plutarch speaks of his "softness and effeminacy of body." 132 Whilst Otho might appear to be a rather irrelevant piece to refer to due to the fact that his public speaking ability was not impacted like the victim in this controversiae he still does serve as a useful parallel that illustrates the severity to which

\footnotetext{
${ }^{130}$ Skaine 2015: 229

131 Gleason 1995: 159

${ }^{132}$ Williams 2010: 169
} 
the Roman people held masculine identity. This works in the case of Otho illustrates the way in which one's image can be tarnished by simple hints at effeminate behaviour therefore serving to neatly parallel with the case in question which contains a man taking these effeminate behaviours, in lieu of appearance, to the extreme. ${ }^{133}$ Plainly put, when it came to Otho all of these actions were viewed negatively when there were only hints towards effeminate behaviour. By contrast, having the victim be one who both dressed up as a woman and, allegedly, dress up as a woman to such an extent that it is now being pondered that he has done this before in order to explain his skill, casts a serious negative image on his character and provide further reason as to why he should remain unable to speak in public.

The advocates then change tone and bring up a common notion found within Roman invective, that being assessing one's current character based upon their past actions, more specifically their action as a youth; 'I pass over everything he did as a youth - I am satisfied to talk only of a single night; he imitated a girl to such effect that he found someone to rape him.-' (Controversiae 5.6.19-22) Dupont defines youth in Roman thought starting around the ages of sixteen or seventeen with one being categorised as such until as late as the age of thirty. ${ }^{134}$ As stated earlier, the trope of attacking the actions of one's youth in order to portray a negative imagine of their current character is very common within Roman rhetoric, perhaps the most well-known example of this appearing in Cicero's Philippic $2 .{ }^{135}$ In this rhetorical piece, Cicero, amongst other things, Cicero uses stories from Antony's past to directly attack his character in ways that parallel the more modern stories through which Cicero is defaming the character of Antony. ${ }^{136}$ All of this is to say that, whilst attacking the character of one's past

\footnotetext{
${ }^{133}$ For more specifics on the primary sources pertaining to Otho see: Juvenal Satires 2.99-109, Suetonius Otho 6.3 and 12.1 and finally Plutarch Galba 25.1.

${ }^{134}$ Dupont: 1989: 229-230

135 Craig 2007: 282-283

${ }^{136}$ See Cicero Philippic 2.45-46, in particular the story of Antony and Curio.
} 
actions as a youth was a common practice in order to negatively impact their current characteristics, the fact that the advocate is happy to pass over such a common practice speaks volumes to their confidence in the case. Ultimately, the advocate would have spoken ill on various actions of the victim as a youth if they felt they needed more examples to further attack his character with, however, since they have opted to not use such tactics but allude to their existence, highlights just how detrimentally the victim's current actions have affected their character in the eyes of the advocate. All of this is to demonstrate just how negatively the victim has been impacted by being penetrated, even if it was against their will.

Moving on, the advocates then speak on the magistrate's behalf when they ask: 'Have I struck a blow? Have I written a slanderous lampoon, or, to mention your particular type of injury, have I raped you?-' (Controversiae 5.6.22-24) These questions are done in a way to question why the victim has even bought this case forward. There have been no physical injuries of violations, such as the one that he received from the ten youths who have in fact been convicted of such a crime. Instead, it could almost be argued that it is in fact the victim who has harmed the magistrate and, by association, his fellow citizens by allowing himself to become unchaste and then flagrantly violating the law put in place to deal with those who have become a dishonourable stain upon society. Clearly, this series of questions is provided in order to demonstrate how absurd the victim's case really is as the magistrate has not injured him in any particular way and yet he still attempts to challenge it. Similarly to earlier, this illustrates how negatively the victim's character and social standing has been impacted by becoming unchaste and that the circumstances for how he became unchaste appear to have no bearing in this scenario. 
Following this, the advocates then address a point directly tied into the Roman value of mos maiorum. According to Kenty: 'Mos maiorum forms a core element of the Romans' collective identity, encapsulating both the real institutions of the Roman state and the value system which supposedly generated and defined them. ${ }^{137}$ More plainly, mos maiorum served as a code of ethics based around Rome's history which helped defined their actions in the present. ${ }^{138}$ The advocates appeal to mos maiorum by stating: 'In our fathers' time, those who were starting off their career in the courts were thought to be acting outrageously if they poked an arm out of their toga. How far from such a character were those who were so modest even in the use they made of something good!-' (Controversiae 5.6.25-230) This clearly shows an appeal to the ways of the past and a lament that the current generation is behaving in a way that does not emulate the virtue of the ancestors. This conjured ideal of someone having too much shame to even have a hint of their arm visible outside their toga clearly contrasts with the image of the victim dressing up in women's clothes. This contrast serves highlight just how depraved the victim's actions were in contrast to what would be viewed as exemplary behaviour in the eyes of the Roman people. Therefore, it is apparent, that the current situation that the victim is in is being blamed for his own, un-Roman, unorthodox, actions. This fact presented by the advocates serves to further the idea that the victim has no one to blame for this predicament but himself and should therefore act appropriately. Once again, the key driving point behind these attacks is the idea that the victim should ultimately be the one blamed for his punishment.

The final point raised by the advocates is a rather simple one which proceeds as follows: 'It is agreed that this man was violated - those who raped him have been convicted.' (Controversiae 5.6.30-31) Once again, the fact that this case has already been dealt with is being addressed.

\footnotetext{
${ }^{137}$ Kenty 2016: 429

138 Roller 2009: 214-215
} 
The youths that raped the victim have already been tried and charged for their actions and logically, in the eyes of the advocates, that is where this discussion should end. It is almost implied that the victim is behaving not only inappropriately but also confusingly as there appears to be no logic to why he is bringing this case forward. He was raped, those who raped him were charged and he is now unchaste which, due to the laws present, means that he can no longer speak in public. There is no confusion or miscommunication that has occurred here and logically, as the victim should be well aware of the laws surrounding chastity, he should now behave in a manner befitting someone who is unchaste. This line of reasoning is fairly logical to follow, however it does nothing to take into account the feelings or circumstance of the victim. Whilst he has indeed lost his chastity, this was not through any willing action of his own and therefore it is worth questioning why he is being treated in the same way as someone who happily and flagrantly shuns the rules of chastity would be. Instead of having any sort of laws to deal with the nuances of such a situation the law outlined in this controversia has an expectation that any person who has become unchaste deserves blame and ridicule, regardless of circumstance. Issues surrounding circumstance, unfair punishment and disregard for the victim shall be explored in depth in chapter 4 however, for the moment, it is worth at least mentioning this type of logic and reasoning as it shows clear flaws and an almost callous nature as to the way in which this system outlined in the controversia deals with such horrendous crimes.

\section{5: The Case For the Victim}

On the other side of the argument, only 35 words of defence are offered on the victim's behalf which proceed as follows: 'It is agreed that he was always grave, always serious; but this was the outcome of a youthful prank. Yet his modesty was so well-known that no-one would believe 
his challenge without a bet.' (Controversiae 5.6.32-35) These sentences are centred around a central argument of defending the character of the victim. In particular the main takeaway is the fact that he would not have dressed up as a woman, in any normal circumstance and that he was only behaving in such a way due to the whims of youth and the challenge of a bet. This idea is then supported by claims around the usual serious and grave manner within which the victim operates in his average day-to-day undertakings. Whilst these are perfectly fine, and rather common, lines of argument they do have a few key issues. Primarily, they are very reactive, clearly done in an attempt to discourage some of the severe accusations made about the victim's character by the other side. Despite this however, these arguments come across as simply too brief and un-substantive to effectively dismantle the arguments raised by the other advocates. Moreover, the defence offers nothing new or unique in order to defend the victim's character, instead behaving almost like a mere formality than a fully composed argument. Whilst it is unclear what the outcome of this declamation was, as stated in chapter one declamations were designed to be a mere exploration of a hypothetical case and based more around arguments than conclusions, it would be reasonable to assume that the outcome of this case would have been in favour of the advocates. The simple reason for this is the rather obvious disparity in the number of arguments offered for the magistrate versus those offered in defence of the victim. Whether this is enough to definitely state that the outcome would have occurred this way in a rather redundant argument to enter, however this does clearly demonstrate a disparity in the number of legal options available to defend a victim versus those designed to dismantle their character, actions, lifestyle and blame in what has occurred. Moreover, this inherent disparity helps to inform the reader on the lines of argument that the elder Seneca and his contemporaries found more compelling as he is recalling these arguments from memory. 


\section{6: Final Thoughts}

All of this is to say that by exploring Seneca the Elder's Controversiae 5.6: 'The Man Who Was Raped in Women's Clothes' a rather clear image begins to appear. This image is centred around the idea of character assassination, victim blaming, questioning of motives and unwanted comparisons. Ultimately, the arguments portrayed within this controversia place far more emphasis on blaming and attacking the victim rather than allowing an exploration into the nuances of the circumstance present. A law situated on absolutes rather than complexities can be found and this results in a system that may deal with the perpetrators of such a violate act but leaves the victim in such a negative situation that their life and social standing will never be able to recover or, arguably, even effectively operate after being branded as unchaste after being raped. Overall, it is clear that whilst the systems in place may deal quickly and efficiently with those that violate a male citizen it allows no exception to ensure that the male citizen that has been raped can carry on their life without the negative consequences of being labelled unchaste. When applying this fictionalised representation back to Roman society, it is fair to state that whilst the Romans may be concerned with preventing the rape of their citizens and ensuring that those who do rape are punished properly, their almost slavish devotion to the notion of chastity ensures that any rape victim shall be negatively impacted from their encounter long after the trauma of the situation has subsided. The negative consequences of such a devotion shall be explored, in both a classical and modern context in the next and final chapter of this thesis. 


\section{CHAPTER FOUR:}

\section{SOURCE COMPARISONS \& MODERN PARALLELS}

\section{1: Analysis of Pseudo-Quintilian \& Seneca the Elder}

Now that both Pseudo-Quintilian's Major Declamations 3 and Seneca the Elder's Controversiae 5.6 have been explored in isolation, it is time to address these sources in relation to each other. The purpose of this section is to highlight both the similarities and differences between the two sources based upon what has been previously stated in chapter's two and three. Particular attention shall be placed upon the way in which both the victim and perpetrator have been presented, the setting of both cases and the importance of chastity within both.

There are a number of key differences between these sources with the first, and arguably most obvious, of these is the fact that, whilst both of these declamations are situated around scenarios within which a man's chastity is threatened it is only Seneca the Elder's controversia that deals with the aftermath of a man actually being raped. This simple fact acts as one of the chief areas of analysis as it allows one to assess the way in which a man is treated after their chastity has been threatened in contrast with how they are treated after their chastity has, forcefully, been taken away. When assessing the notion of being forcefully penetrated, scholars such as Williams argue that the stereotypical conception of someone in the receptive role was that they either fell into the category of women, slave or boy, or that they were some sort of effeminate abnormality. ${ }^{139}$ This interpretation has been challenged some in recent scholarship. See the work of sources such as both Kamen \& Levin-Richardson 2014 and 2015, Ormand 2009 and

${ }^{139}$ Williams 2010: 7-9 
Langlands 2006 for explorations of the nuances to be seen within cases of penetration and agency. As expressed within chapter one of this thesis, these sources challenge the generalised conception of the penetration paradigm that defined scholarship surrounding sexual agency. Regardless of these nuances however, it is clear that, due to a rape being a form of assault and a violation of ones' autonomy ${ }^{140}$ these nuances do not apply to the argument of this thesis. Instead, one is faced with the fact that in a situation where a male has been raped the genre of declamation would view this figure in the same light as someone who was willingly and blatantly effeminate and improper. In relation to the declamatory cases of the Elder Seneca and Pseudo-Quintilian, there is obviously a dissonance between the way in which the victims are being portrayed and viewed by those around them. This all stems back to the fact that only of victims was subjected to this emasculating act, this being the victim within Seneca the Elder's Controversiae 5.6, whereas the soldier, Trebonius, in Pseudo-Quintilian Major Declamations 3, was able to ensure that his would-be rapist was unsuccessful by killing him before he had his way with him.

This disparity between the conceptualisation of the central figures can be seen throughout the two texts. In Seneca the Elder's Controversiae 5.6, the victim is berated and ridiculed for allowing himself to get into a position which resulted in him being raped. Because of this, he is now being treated as though he were a cinaedus, this being a man who willingly allows themself to be sexually penetrated by others ${ }^{141}$ : 'Give him girls' clothes, given him darkness he will get raped -' (Controversiae 5.6.16-17). By contrast whenever the soldier is referred to in Pseudo-Quintilian's Major Declamations 3, he is described as being 'perfectly chaste' (Major Declamations 3.8). Furthermore, when directly contrasted with his seducer, Lusius,

\footnotetext{
${ }^{140}$ Foxhall 1998: 132-133

${ }^{141}$ Holmes 2012: 79
} 
Trebonius is stated as being 'a man braver than himself' (Major Declamations 3.1). Both of these references illustrate a clear disparity between the positive portrayal of Trebonius, which was explored in depth in chapter two, and the negative representation of the victim. In fact, when searching for a more direct character to parallel with the victim in Seneca's controversia one would be better served looking at the representation Lusius with focus being placed on how both of these figures are being treated in their respective texts.

By allowing this rape to happen to himself the victim is no unable to speak in public and is viewed as damaged in the eyes of those present to judge him 'Perhaps this too is the result of a bet, that he should perhaps speak in public, though unchaste' (Controversiae 5.6.12-16). In a similar fashion, Lusius is being portrayed as having 'an eternal shame' (Major Declamations 3.1) and being passion to a 'perverted lust' (Major Declamations 3.2). Whilst I would not be so bold as to state that these declamatory cases are attempting to illustrate that one should view the victim and Lusius, the attempted rapist, in the same light it is fair to note that there appears to be far more in common between their portrayals than there is between a comparison of Trebonius and the victim. All of this is to say that, these two figures are portrayed as having different origins for their current negative image, Lusius with his perverted lust that drives him to acts that are deemed horrific and unnatural ${ }^{142}$ and the victim with his unchaste nature thus lowering him to the status of a cinaedus. Despite these however, both Lusius and the victim are portrayed in ways centred around shame for acting inappropriately for an idealised male citizen. Because of this both of them have been ostracised, to some extent, from society and the repercussions of this are shown in the way in which the declamations address them respectively.

${ }^{142}$ Langlands 2006: 270-271 
All of this directly parallels with the idea illustrated in chapter three that, whilst the case Seneca describes logically is about vis, it ultimately turns into an exploration of the victim's stuprum. This is to say that, by analysing these controversiae in contrast, one can discern the disparities in the portrayals of the two rape victims. The primary cause of this disparity stemming from the simple fact that one of them was able to defend his chastity whilst the other was unsuccessful in the endeavour. ${ }^{143}$ This results in the rape victim of one declamation being attacked in the way similar to the way the rapist of the other declamation is as they are both now portrayed as distanced from society due to their actions. Ultimately this shows the divide between the way in which these cases dealt with someone who was raped versus someone who was only threatened with it. Moreover, it highlights the debilitating effect that having your chastity violated does to the male citizen, as the victim is now being portrayed in a more comparable way to a violent criminal than Trebonius, a man who has gone through a far more similar experience to himself.

Moving on, the next area of comparison and analysis is the way in which both of these sources were written. As was explained in chapter three, the Elder Seneca's source is far more fragmentary than a traditional controversia, particularly in contrast with the major declamations of Pseudo-Quintilian. Referring back to Bablitz's definition of Seneca's writing style, one can recall that his works followed a specific formula of 1) preface, 2) central law, 3) arguments for both sides 4) the declaimers division and 5) the declaimers colours. ${ }^{144}$ Then, by referring to Sussman, the missing sections of the Elder Seneca's Book 5 are highlighted as

\footnotetext{
${ }^{143}$ It is worth briefly pointing out that Seneca the Elder's Controversiae 5.6 never explicitly states or explores the way in which the victim attempted to avoid being raped, although due to the number of youths who did rape him it is not hard to imagine how he was unsuccessful in his defence. Regardless of this however it is clear that this case was still a rape and at no point were the actions willing on behalf of the victim simply due to the language utilised throughout the declamation, most notable the fact that it is titled 'The Man who was Raped in Women's Clothes.'

${ }^{144}$ Bablitz 2007: 3
} 
being the preface and both the declaimers division and colours. ${ }^{145}$ In direct contrast to the fragmentary nature of Seneca's source, and the condensed way in which he composes his controversiae, Gunderson highlights how: 'The Major Declamations are very long and polished. They appear to be best suited to performance rather than the inculcation of detailed precepts via specific examples.' ${ }^{146}$ This sentiment is also shared by Bernstein who states: 'The collection [in reference to the Major Declamations] presents developed speeches rather than the brief excerpts preserved in the Elder Seneca or the compressed arguments of the Minor Declamations. ${ }^{147}$ These sources clearly show the disparity seen within the writing style of these declamations with this making them very different pieces of writing to approach because of it.

Whilst the speech like style of the Major Declamations helps fully develop the themes and nuances for the viewer the much more compressed style of the Controversiae invites much more room for personal analysis and a sense of elaborating upon the ideas that a merely hinted at throughout. This is not to say that further analysis of the Major Declamations is impossible, rather the point this thesis is making is more centred around discerning the differences between these sources purpose with this becoming apparent when analysing the reason for their creation. Notably the Major Declamations is far more about exploring the detail that is provided whereas the Controversiae is focused on one adding the detail and implications that the smaller work only hints at with each sentence. This distinction is important to impacts the lens through which one analyses these sources, with the writing of Seneca the Elder encouraging one, originally his sons by but proxy anyone who reads $i^{148}$, to elaborate and analyse the points raised in order

\footnotetext{
145 Sussman 1971: 286

${ }^{146}$ Gunderson 2003: 3

${ }^{147}$ Bernstein 2013: 8 This quote has also been edited by me, these edits being the brackets, to help with reading ease.

148 Gunderson 2003: 29-33
} 
to further develop the implications and nuances of his arguments. By contrast the lengthy speech found within the Major Declamation serves more as a demonstration of the authors oratory prowess and legal knowledge with Bernstein arguing that: 'The audience's acclamation, not the fictional jury's never-delivered verdict, constitutes the victory in a controversia. ${ }^{149}$ By this Bernstein is arguing that for the author of the Major Declamations in particular their primary goal is not to win a case but to win over their peers who are listening with this speech serving as the most convincing way of garnering their attention and affection. Ultimately whilst the writing of Seneca the Elder's Controversiae is about educating and learning the writing of Pseudo-Quintilian's far more concerned with impressing.

This distinction is important to understand as it helps to provide a number of answers to issues that have arisen throughout this thesis. The first of these is the complications of PseudoQuintilian's Major Declamations 3 having a historical setting. As was defined by Dinter ${ }^{150}$ controversiae were done as mock legal speeches with the setting for these being entirely fictional and removed, to a degree, from Roman society. This separation was explored and given a title by Russell, this being the fictionalised Greco-Roman city-state known as Sophistopolis. ${ }^{151}$ However, in direct contrast to this definition, Major Declamations 3 takes place in a historical setting, not only that but it details a well-known case dealing with notions of chastity and status. Whilst earlier in the thesis it was posited that this historical setting serves to highlight the importance with which the Romans viewed rape cases, as controversiae cases were often centred around the worst crimes that the Roman people could imagine. ${ }^{152}$ This answer only partially goes towards explaining why Pseudo-Quintilian chose to adopt a historical setting, an unorthodox act for any controversia. The additional reason in question,

\footnotetext{
${ }^{149}$ Bernstein 2013: 9

${ }^{150}$ Dinter 2015: 2

${ }^{151}$ Russell 1983: 21-39

152 Dinter 2015: 3
} 
that this thesis suggests, is that Pseudo-Quintilian's work, being one that was all about demonstrating learned prowess to his contemporaries, deploys a historical setting as it both provides a deeper level of praise from the audience, due to the skilful way in which he dramatizes this historical event and it provides a certain level of credence to his side of the argument, this being that Trebonius should be acquitted of the charges laid against him. This credence occurs as historically the soldier in the army of Marius was exonerated of the charge of murder, with certain sources even illustrating a certain level of fame and praise given to the soldier from Marius himself. ${ }^{153}$ Therefore, by having Pseudo-Quintilian's declamation on the topic only provide an argument for the side that historically wins a certain level of credibility is being attached to his speech thus making it appear all the more convincing towards a crowd that he is trying to convince and impress. Ultimately, the reason for Pseudo-Quintilian utilising this historical setting ties back into the reasoning outlined above by Bernstein as to how one is successful in a declamation, this being that the declaimer wins over their peers, ${ }^{154}$ with the deployment of this historical backdrop further ensuring that Pseudo-Quintilian will be successful in this outcome.

Furthermore, the writing style also differs in the way in which the cases are argued, and by who argues them. The longer Major Declamations only presents one side of the argument, that being the advocate for the accused Trebonius. By contrast the Controversiae 5.6 explores cases raised by both sides with a larger portion of the work focusing upon claims made against the victim. This distinction obviously impacts the image with which one views the central figures of both controversiae, most notably the victims. It is fair to state that declamations do not hold a consistently neutral tone. Even when arguments for both sides of the case are offered, which

\footnotetext{
153 See Plutarch Life of Marius 14 for his recount of the events.

${ }^{154}$ Bernstein 2013: 9
} 
are not always present, the highly evocative tone utilised by the declaimers ensures that the characters within the cases are portrayed in only the most positive or negative of ways. This results in a biased portrayal of the characters within both controversiae with these extreme portrayals being utilised order to lend the side the declaimer is arguing for more credit. This can be seen specifically in Pseudo-Quintilian's Major Declamations 3 were all comments regarding Trebonius are positive, at worst in a back handed way. By contrast, all those regarding Lusius are centred around how depraved he is. This is done as the declaimer is providing a speech with the specific purpose of defending Trebonius for murdering Lusius and an easy way to do this is to paint Lusius, a murdered man who can no longer defend himself from such allegations, in a negative light and Trebonius in a positive one. Whilst Seneca the Elder's Controversiae 5.6 at face value would not fall into this bias due to the fact that arguments are made on both sides of the case. As has been explored in chapter three, the vast majority of the case does deal with those in favour of the magistrate over the victim and therefore, even though there are arguments in defence of the victim, the overwhelming majority of the case centres around attacks of his character and actions and therefore this bias is still present, even to a lesser degree. This is to say that, even the more balanced case offered by the Elder Seneca still portrays the victim in a biased view. Moreover, the representation of Trebonius and Lusius in the Major Declamations is inherently one sided due to the fact that this controversia only argues one side of the case in question.

What is interesting about all of this is that the case in which the character of the victim is defended is the one in which he was only threated with raped. By contrast, the case that spends the overwhelming majority of its time attacking the victim's character is the one dealing with a man who has been raped. This links back to this chapter's earlier discussion on the way in which these two characters are being portrayed based upon their chaste status with the one who 
is now unchaste being viewed in a far more negative light based upon the simple fact of them being unchaste. Moreover, this links directly into notions of stuprum and vis and their portrayal within this case. As has been explored in this thesis' introduction, Nguyen states how vis specifically applies to cases of rape involving physical violence, notably pertaining to instances of lust. ${ }^{155}$ Stuprum, on the other hand, was more focused on any irregular or promiscuous sexual act including homosexuality. ${ }^{156}$ When looking at Controversiae 5.6, it at appears that vis will be the central definition for the rape that occurred with it being explicitly stated that when it came to dealing with the ten youths, the victim: 'accused them with violence, and had them convicted.' (Controversiae 5.6.4) This therefore holds that the case should be dealing with a discussion of vis as that is what the youths were tried under. Instead the victim is subject to a dissection of his character based upon the notion of stuprum as he is portrayed, not as the victim of a violent assault, but as being involved in a promiscuous homosexual act. In a similar fashion, when addressing Major Declamations 3, Langlands exclusively refers to the assault as a form of stuprum $^{157}$. This is surprising as the assault again falls more under a category of violence with the case itself supposedly being centred upon the murder of Lusius, however it ultimately devolves into a discussion of protecting Trebonius from stuprum. All of this is to state that both cases end up being far more concerned with stuprum than vis, even in instances where vis is specifically stated. This can be attributed to the fact that due to the homosexual nature of the rape the Romans have greater comfort in discussing stuprum as it helps to maintain the ideal that these actions are irregular and distinguished from the traditional form of rape that was vis.

\footnotetext{
155 Nguyen 2006: 83

156 Nguyen 2006: 83

${ }^{157}$ Langlands 2006: 265-269
} 
Ultimately, when exploring Pseudo-Quintilian's Major Declamation 3 and Seneca the Elder's Controversiae 5.6 in parallel one central theme that divides these two works emerges, that being the way in which the works go about describing and detailing their central figures of Trebonius and the victim respectively. As has been made apparent, whilst Trebonius is largely praised for his actions as a paragon and defender of chastity the victim is attacked and even ridiculed for the actions that resulted in him being raped. This disparity is largely tied to the simple fact of one source dealing with a man who successfully defends his chastity from the threat of rape and the other living with the many consequences of having that chastity forcefully taken away. This disparity is central to understanding the way in which these authors chose to represent the importance of chastity, both in the fictionalised declamation setting of Sophistopolis and, to an extent, Roman society at the time of the writing of their works. A threat to chastity was seen as a direct attack however if one is able to successfully defend their chastity then their status in society is largely intact and actions that were taken in the name of this defence can be overlooked even if they violated other laws. By contrast, one who has unsuccessfully defended their chastity and thus become the victim of a rape is liable to ongoing negative consequences regardless of the circumstances leading up to their assault and is no longer considered a true member of society. This fact ties directly back into the notion that all discussions of male sexual assault resort to discussions of stuprum even when vis would be more appropriate. The primary difference between the two sources implies a lot about the way in which Roman society dealt with men who have been threatened with sexual assault or actually sexually assaulted. These representations parallel in many fascinating ways with society today. The next, and final, section of this thesis shall explore these parallels in order to assess the nuances of rape representation and survival in both this ancient setting and in modern times. 


\section{2: Modern and Ancient Definitions of Rape}

Before delving into a discussion on rape in the modern world, the immediate question to address is why one would consider such a conversation to be necessary when assessing the nuances of male rape representation in two specific declamation cases. The answer to this question arises in Holmes' 2012 book Gender: Antiquity \& Its Legacy where, in the introduction, Holmes states: 'the debate about the future of gender needs to be based on an understanding of its past. ${ }^{158}$ This points outlines how a study of gender in the ancient world helps one to understand and come to terms with the modern representation of such a topic and even, in extreme circumstances, help to inform our current society and future decisions. Holmes' work reaffirms such notions: 'If we can get a sense of the entanglement of the classical past in the field of gender studies, we might be able to gain some insight into how we can think differently not just about the history of gender but also about its future.' 159

This sentiment is a fair one to uphold as the idea of referring to how past generations have acted and then attempting to act in direct response to those actions is a universal factor of the human experience. ${ }^{160}$ More specifically, when applied to the central topic of this thesis it is clear that issues surrounding masculine identity exist to this day. Moreover, to be blunt, it is overwhelming apparent that male rape does still happen in our modern society. All of this means that between the ancient attitudes towards this topic and modern realities of these issues,

\footnotetext{
${ }^{158}$ Holmes 2010: 1

${ }^{159}$ Holmes 2010: 2

${ }^{160}$ As illustrated in chapter three of this thesis the notion of mos maiorum was influential to the way in which Roman citizens conducted themselves with this notion stemming from the Romans reflecting on the way in which their direct descendants acted and attempting to emulate this perceived greatness. For more modern example on the other end of this spectrum, in a world that is constantly striving for greater equality and recognition of all reflections on the way in which certain groups have been marginalised in the past directly informs arguments surrounding how they should be better treated in the future. This is to say that the idea of collective action in response to past actions appears both in ancient and modern society and can result in attempts to emulate or distance oneself from the behaviours and actions of the past.
} 
parallels are not only hinted act but clear to any who are observant. Therefore, a discussion of this topic in the ancient world without at least an acknowledgement of the modern parallels would be dangerously reckless as it refuses to analyse a key component of study. Overall, by looking at the modern day this thesis is furthering one's understanding of both the primary sources being analysed and providing a lens through which these sources can be applied to the modern day.

Onto the discussion at hand, the realities of rape, specifically male rape, in the modern world. Much like in the ancient world the term rape actually holds a certain degree of nuance with there being a number of ways in which it is defined. Skaine's work Abuse: an Encyclopedia of Causes, Consequences and Treatments explores the way in which rape is defined and ultimately divides it into three distinct categories, these being statutory rape (the act of having sexual intercourse with somebody under the age of legal consent, this age changing depending on the country), marital rape (the act of non-consensual sexual intercourse between partners) and date rape (the act of forcible sexual intercourse committed against an individual during or after a social engagement). ${ }^{161}$ In addition, Nguyen offers the definition of rape as: 'unlawful sexual activity (esp. intercourse) with a person (usu. a female) without consent and usu. by force or threat of injury.' ${ }^{162}$ These definitions, whilst by no means definitive, as there are certain circumstances that could be defined as rape that do not specifically fall into any of these categories, do help to illuminate the chief concerns in modern society surrounding what qualifies as rape. These largely fall into two chief ideas the issue of age and the issue of consent.

\footnotetext{
161 Skaine 2015: 230-238

162 Nguyen 2006: 76
} 
The issue of age is rather straightforward, the country that a modern citizen lives in shall determine a minimum age requirement that someone must be before they are old enough to legally consent to the act of sexual intercourse, locally this age is 16 . This fact stems back to the obvious and clearly understandable concern of young people being forced into sexual situations without being mentally developed enough to fully understand that what is happening to them is wrong or having the mental maturity to consent to such actions. This concern is elaborated upon by Glaser and Frosh in their book Child Sexual Abuse: Second Edition when they address the fact that children, due to their age as well as their physically and mental limitations are entirely dependent upon adults and therefore psychological manipulation resulting in sexual misconduct can take place. ${ }^{163}$

The other two definitions of rape, these being marital, and date are both centred upon the idea of consent. Regardless of who is the perpetrator, these definitions fall back to the idea that the sexual encounter was one where consent was not given and therefore it is classified as a rape. An interesting fact about these definitions of rape is that they actually count something as rape that the ancient Romans entirely disregarded, this being the idea of a partner being able to be your violator. In the ancient world a wife could not be raped by their husband, there was no further complication as she was now the man's property and he could therefore do whatever he wanted. This notion has actually held true, in various ways, for much of human history with Skaine identifying the fact that marital rape is one of the newest definitions for a rape, first being legally recognised in $1975 .{ }^{164}$ Moreover, when addressing rape in ancient Rome in contrast with modern definitions, Nguyen stated that: 'for the Romans, laws on sexual behaviour including rape, adultery, and seduction focused on the woman not for physical

\footnotetext{
${ }^{163}$ Glaser and Frosh 1993: 4-14. For further discussions on child sexual assault see Bagley and King 1991 for a book more focused on the healing process than the nuances of the problem.

${ }^{164}$ Skaine 2015: 237
} 
protection of the woman in her own right, but because she was the necessary vehicle for carrying on the oikos, and for this reason she was of state interest.' ${ }^{165}$ This difference addresses what appears to be a shift in societal attitudes towards sexual assault towards a focus on who the people involved were to a more central focus on whether consent was given on both sides. This shall become more relevant when addressing the differences between male rape in both societies and the parallels that can be addressed.

Whilst one might expect this change in attitude, and therefore change in the acceptance of rape victims regardless of their relationship to the perpetrator, to result in a decrease in the number of rapes occurring. This does not appear to be the case. When analysing a series of reports into the number of reported rape cases in the United States ranging from 1992 to 2010, Raphael found that between $10.6 \%$ to $16.1 \%$ of women claimed to have been sexually assaulted at least once in their life. ${ }^{166}$ In terms of population this number translates to between 11.7 to 18 million women in the United States. ${ }^{167}$ Skaine on the other hand assessed the number of overall rapes, regardless of gender in the United States and produced some figures. She says that every two minutes someone in the United States is raped, 9 out of 10 of these victims are women and, most notably to this thesis $3 \%$ of American men are victims of a successful or attempted rape in their lifetimes. ${ }^{168}$ This figure would translate to a little over 4.5 million men. ${ }^{169}$ On a more local level, in 2020 the New Zealand Ministry of Justice published findings that indicated that $11 \%$ of women had experienced either attempted or successful sexual assault with a contrast of $2 \%$ of men reporting the same. In relation to men, this figure would translate to 47,650

\footnotetext{
165 Nguyen 2006: 81

166 Raphael 2013: 86

167 Raphael 2013: 86

168 Skaine 2015: 228

169 This figure was taken by assessing the number of men in American according to a 2010 CDC study, this being 151.8 million and then calculating $3 \%$ of that number.
} 
men. ${ }^{170}$ By contrast, New Zealand male sexual support group Mosaic states that 1 in 6 men experience sexual abuse before the age of 25 . As is apparent when comparing the local studies of either country, the numbers do not match each other, certain studies will indicate a higher number of sexual assault cases and others less with these disparities not being a mere handful of people but tens of thousands if not millions in disparities.

It is fair to state that this fact is frustrating when attempting to definitively state how many instances of rape there are, and by contrast what percentage of these cases are men. However, it does help identify two key facts. The first of these is that, regardless of the case or the country it is clear that male sexual assault is a mere fraction of female sexual assault. This is important as it concurs with the disparity in ancient sources that discuss male rape versus those that address female rape. This fact implies a strong connection to the idea that instances of male rape have always been less prevalent regardless of which era one is addressing. Once one accepts this fact it becomes all the clearer as to why sources and studies addressing rape, both in modern times and the ancient world have had this clear female focus as statistically that is what rape is referring to the majority of the time. Whilst this thesis is by no means attempting to understate the seriousness of these cases or the fact that studying such cases is highly important, this does correlate with the central idea of this thesis, that male rape is being understudied and underrepresented in scholarship and that an analysis of rape should hold a more universal view and exploration on the various forms of rape than it currently does. Additionally, when it comes to understanding the true statistics of rape in the ancient world one would be remiss to not mention the complications that slaves and their status raise. As was explained in chapter one, slaves were non-citizens and therefore could not be victims of rape.

\footnotetext{
${ }^{170}$ This figure was calculated by taking the number of male NZ citizens according to the 2019 census: 2,384,745 and then calculating $2 \%$ of that number.
} 
When exploring this notion, Nguyen explains how to the Romans there were groups including slaves, prostitutes and foreigners who could not be raped, according to Roman definitions of it, due to their social status. ${ }^{171}$ Acknowledgement of this fact further complicates the issue of accurate statistics as it is impossible to know how many rapes occurred to people that fit any of these categories as they would not have been thought of as rape in the Roman mindset and therefore would not have been worthy of mention or further examination.

\section{3: Comparisons Between Modern Ideology \& the Controversiae}

The other key fact that these statistics illustrate is that no one really understands the exact extent to how prevalent rape is in society. Ullman's book Talking About Sexual Assault: Society's Response to Survivors expresses this idea when discussing the modern day and stating that it will simply be impossible to determine how many rape cases there actually are. ${ }^{172}$ Her reasoning for this is due to the fact that many rape victims do not even disclose the fact that they were raped and that even when they do it is not in an official, recordable capacity. ${ }^{173}$ For Ullman, this helps to explain the varying range of statistics on the topic such as the range that was represented earlier. ${ }^{174}$ This stems back to the fact that the vast majority of rapes go unreported and therefore unrecorded with those compiling these statistics attempting to justify for this disparity. This sentiment is one that can be seen in the primary sources with the wild proclamations of the advocate in Major Declamations 3 stating: 'Is this why prostitutes are kept away from the army and it is forbidden for women to enter the camp? I guess that there is no need for them.' (Pseudo-Quintilian Major Declamations 3.12) The claims in this statement,

\footnotetext{
${ }^{171}$ Nguyen 2006: 85

172 Ullman 2010: 44

${ }^{173}$ Ullman 44-45

${ }^{174}$ Ullman 2010: 45-46
} 
though a clear form of exaggerated hyperbole, do two things. The first is that they illustrate the fact that soldiers, in this extreme, could be viable sexual partners, hence the lack of need for prostitutes. Moreover, this statement heavily implies that there are far more instances of male sexual assault taking place within this military camp then the one that is currently being examined. Here the advocate is addressing both the possibility of such instances taking place and the notion of a hyper-sexualised society that not only accepts such actions but provides scenarios where these acts can occur without any negative repercussions. Again, whilst this example if deliberately designed as an extreme the mere mention of this idea relies on a concern that this could be a reality and thus implies further possibilities. This implication spreads further than just the immediate camp in question as the fact that prostitutes and women were unable to enter a Roman military camp applied to all, not just the one in question with the advocate implying that they are not needed due to all of the sexual activity that is rampant without them.

In a similar fashion, whilst not explicit implication is made within Controversiae 5.6 as to further instances of sexual assault the way in which the topic is approached and dealt with throughout the controversiae speaks volumes. As was hinted at in chapter three, when addressing the line: 'Give him girls' clothes, give him darkness - he will get raped. -' (Seneca the Elder Controversiae 5.6) the almost dismissive tone here conveys an acceptance of a society with a sense of aggressive sexuality with the fact that the victim got assaulted being viewed as a certainty rather than a possibility. Both of these quotes imply that, much like our modern society, the ancients were aware of the realities of rape in their society and the prevalence to which it occurred regardless of whether it was reported or not. It would be perhaps too much to say that a discussion of these ideas under the lens of the controversiae explicitly states that a sexualisation to the degree explored in these cases took place. This being 
due to the hyperbolic nature of declamation itself. However, it is fair to illustrate the idea that by expressing such concerns so blatantly the authors were aware of such issues, though to a less extreme degree, within their own society.

Moving forward, it would be almost callous to state how victim blaming plays a part in discussions surrounding rape in modernity. The works of Niemi and Young have created what they call 'The Path Model of Blame' a model that outlines the ways in which one can have blame placed upon themselves either internally or externally given the circumstances of their rape. ${ }^{175}$ The model in question illustrates just how easy it is for blame to be passed on the victim with only one potential way that a victim can hold no degree of blame, this being a guarantee that they did not cause the rape in any capacity. ${ }^{176}$ Whilst this degree of certainty might seem easy to obtain, the exploration of rape myths below will illustrate the ways in which society has constituted an environment where victims often feel some sort of accountability in the assault that occurred.

Writings such as Suarez and Gadalla have identified the cause of this self-blame stemming down to the notion of 'rape myths - false beliefs used to shift the blame of rape from perpetrators to victims' ${ }^{177}$. When surveying this very notion in relation to cases of male sexual assault Abdullah-Khan found that respondents believed that factors which contributed to one being raped included the following: 1)the notion of being in the wrong place at the wrong time, 2) the use of drugs either by the victim, perpetrator or both, 3) bad luck, 4) the choice of locations that one frequented (notably if they went to places favoured by homosexuals), 5) being imprisoned, 6) having a mental illness and 7) merely being homosexual themself. ${ }^{178}$ If

\footnotetext{
175 Niemi and Young 2014: 231

176 Niemi and Young 2014: 232

177 Suarez and Gadalla 2010: 2010

178 Abdullah-Khan 2008: 15 8-160
} 
any one of these applied than respondents believed a man was at a higher risk of being sexually assaulted. Notably, the vast majority of these responses stem back to the idea of the victim's choice and behaviour having a large impact on whether or not they would be put into a position within which they can be sexually assaulted. Furthermore, Abdullah-Khan found that in addition to these factors the majority of respondents also agreed that the stereotypical reasons for why a woman can get raped also apply to men. Ward explored these reasons with the ones that explicitly differ from those stated in Abdullah-Khan being as follows: dressing inappropriately so as to provoke someone to rape them, making false claims against a man, their actions asking for it and an ultimate disregard for the circumstance and sentiment that women should just relax and enjoy it. ${ }^{179}$ All of these myths surrounding why someone can be raped centre around the notion that one has a direct impact on whether or not they will be raped. When addressing the realities of why these rapes occur Ullman says that these rapes are connected to broader societal and social issues with effective treatment centring on changing the way in which a society views these rape myths in order to push them aside and address the real issues at play. ${ }^{180}$ Ultimately it is not about changing the way in which a victim has acted but rather reinventing the way in which society views victims, perpetrators and the realities of rape overall.

Now that an understanding the way in which modern society places blame on a victim has been addressed it is time to address the explicit parallels that can be seen between these attitudes and those expressed in the declamation cases studied. In her research, Raphael addresses a 2011 case where a group of 18 young men were charged with raping an 11-year-old girl. ${ }^{181}$ The article which addressed this case highlighted reports from local residents who blamed this rape

\footnotetext{
${ }^{179}$ Ward 1995: 38-39

${ }^{180}$ Ullman 2010: 8-9

${ }^{181}$ Raphael 2013: 61
} 
on factors including one unnamed resident in particular who said that the girl dressed older than her age (apparently wearing makeup and clothing more appropriate for a woman in her 20s). ${ }^{182}$ This account directly parallels the accusations made against the victim in Controversiae 5.6 where it is stated that: 'He put on women's clothes, made his hair look like a woman's, put on alluring eye-shadow girls use, coloured his cheeks'. (Controversiae 5.6.1012) These facts are then used to justify why he was raped and attack his character as he was dressing in a manner unbefitting a male. In the modern parallel the girl is being accused of exactly the same thing, dressing in a way unbefitting (this time because of her age not gender) and dressing up in such a way so successfully that it invited a group of young men to rape her. To say that the parallels between these two instances are striking would be an understatement. This comparison serves to highlight how connected modern sensibilities towards rape are with those found within this controversia. These parallels are important as they help to demonstrate just how comparable modern sensibilities are to notion expressed nearly two millennia ago.

The notion of blaming the victim in Major Declamations 3 is a little more understated than the direct attacks made in Controversiae 5.6. The chief area of concern is expressed when the advocate is detailing the ways in which Lusius may have become interested in Trebonius: 'What attracted him? The way the soldier ran in the forefront before the standards; the way a raw recruit outstripped veterans' the way he came back caked with dust and blood. It was this, the very fact that he was such a man. Beauty and youth are vulgar enticements: there's nothing like sleeping with a brave soldier.' (Major Declamations 3.6) The blame being passed on here relates to the notions explored earlier, this being the idea that the actions of Trebonius directly resulted in Lusius attempting to rape him. This thesis has found no direct modern parallel case to that found within this source. However, what is of interest here is not a case parallel but

182 Raphael 2013: 61-62 
more an examination of the notion that Trebonius is directly at fault for enticing Lusius into his attempted rape. As described, Trebonius merely acted as he should have on any given day however one is led to believe that these actions are what resulted in him becoming a target for rape. This very notion links to the idea of rape myths and the commonly held misconception in modern society that the victim has a direct part in their being raped. This sentiment appears in the ancient sensibility as it is portrayed as almost inevitable that Lusius, or another like him, would become attracted to Trebonius given the supposedly irresistible allure of the way he acts and behaves. All of this is to say that the notion of one having a direct impact upon whether or not they shall be raped is a factor that appears across both societal lenses which this thesis is examining.

Furthermore, in Major Declamations 3 there is the notion that Trebonius' actions at the time were limited due to the power dynamic at play between him and Lusius, his tribune. This is expressed when the advocate goes through a hypothetical of what Trebonius could have done instead of murdering Lusius with it concluding as follows: 'And so I suppose he should wait until dawn in order to lodge a complaint with the proper authority: his tribune!' (Major Declamations 3.9). The status of Lusius as a Tribune is immediately explored further with this hypothetical: 'And so, to take things a step further, one can even hope that he will perhaps get a promotion for this good service of his, he will lead companies, and other will serve with under him.' (Major Declamations 3.9). Both of these points lead back to the simple fact that Lusius is the direct superior of Trebonius and therefore his options for lodging a complaint against Lusius for his actions are severely limited and perhaps he should allow Lusius to have his way with him in order to ensure a better future with the army. This leads directly into modern tales of sexual assault where one needs only take a passing glance at the local news to be informed of similar cases surrounding people only bringing to light instances of sexual 
assault long after the fact due to concerns related to their status in any given scenario, notably a job or family relationship, being negatively impacted if they choose to complain. It is situations like these that have further increased the already limited way in which society addresses instances of rape as many people are in a situation where they feel it is impossible for them to come forward or that even if they did their testimony would be largely ignored or covered up by their direct superior. This parallel demonstrates the fact that both ancient society and modernity are plagued with the complexity that many victims are trapped into a no-win situation when it comes to lodging effective complaints against their would-be rapist due to prevailing power inequalities.

The final area to address is that of the way in which the victim is represented after their rape. Throughout Controversiae 5.6 it is apparent that the fact that the victim has been raped is directly impacting his daily life. As was expressed in chapter three, the victim is now being treated as through he willingly allowed his chastity to be violated and then publicly declared himself as unchaste. The ramifications of this are clear and shall remain with him his entire life. In a similar fashion, in Major Declamations 3, Trebonius (or rather the advocate) is now needing to publicly defend him with the conversation becoming more focused on the threat to his chastity and the actions required to defend it. The ramifications of this attempted rape shall be nowhere near as severe for Trebonius then the fate suffered by Lusius' victim, in fact a look at the history of this incident demonstrates that Trebonius actually obtained a higher status because of this. Despite this however, it is clear that in the immediate aftermath of this threat to his chastity Trebonius was then doubted, questioned and forced into a defensive posture where he needed to attest to his rightful status as a proper citizen. Moreover, the fact that he needed to defend himself in such a way had direct impacts on his masculine image and the way in which he was spoken about, notably by his own advocate. These two cases therefore 
demonstrate that if one's chastity is violated, or even merely threatened, they shall be dealing with the negative repercussions of this in their public life for the rest of their life and even in an event of an attempted rape the victim needs to deal with the distress of defending themself and their actions in the short term.

When looking at instances of rape in modern times it is clear that similar challenges exist. As has been explored above, a key area of many rape myths is the notion that one has direct agency in becoming the target of a rape. Furthermore, many cases in modern times are immediately met with questions such as what one was doing before they were raped and whether or not they invited this assault in any way shape or form. In his writings on the impact of rape on male victims, Abdullah-Khan demonstrated that a number of key negative consequences were common amongst rape survivors with these including: 1) nightmares, 2) eating disorders, 3) drug and alcohol abuse, 4) difficulty sleeping, 5) relationship issues, 6) sexual difficulties, 7) a continual need to take time off work, 8) avoiding going out either alone or at night or both and 9) depression along with either thoughts of suicide or attempted suicide. ${ }^{183}$ All of these factors are clear indicators of the continual negative impacts that being raped have upon a man with many of these symptoms relating back to the emotional trauma of the situation manifesting itself in various ways. By contrast to the attitudes expressed in the declamation cases studied, there is no clear direct law that negatively impacts a man's life or his manoeuvrability within society if they are found out to be a survivor of rape. However, taking the list of factors into account it is clear that the quality of their life and their ability to function effectively within society can be greatly impacted as a result of the rape, especially if the perception of what happened comes to be regarded as stuprum enjoyed more than vis endured. The key contrast between the way in which the impact of being raped is addressed in modern times in contrast

${ }^{183}$ Abdullah-Khan 2008:196-197 
with these ancient sources is that the impact expressed and of chief concern to these sources were that of one's status within the public aspects of society. By contrast modern sources seem to be taking more and more of a focus on the way in which one is mentally and psychological impacted after a rape and addresses these problems as the root cause for any physical difficulty that one might be having in society in the aftermath of said assault.

Bringing all of this together it is clear that a number of similarities are still present between the way in which these declamation cases of Seneca the Elder and Pseudo-Quintilian address their rape victims and the way in which modern society views rape. Both areas of study indicate that the degree to which rape occurred in both societies is far higher than any recorded figure can provide. Furthermore, the concept of blaming the victim for being raped is a universal across all areas with this sentiment leading back to the notion that one has a direct agency in whether or not they shall become raped. Both areas of study also demonstrate, to at least a small degree, the idea that there are complexities surrounding merely identifying and laying charges against all rapists, as they can often be socially higher than their would-be victims for a variety of reasons. The main disparity that can be seen does not actually focus on the way in which either society views victims before, during or in the immediate aftermath of the assault, but rather on how society deals with victims in the long term. It is clear that the declamatory society, Sophistopolis, and by association, Roman society viewed male victims of rape as equally accountable as someone who had willingly and flagrantly given away their chastity to base desires. These victims were therefore removed from aspects of public life and status and would experience the ramifications of this assault for the rest of their life. By contrast, modern society does not explicitly ostracise victims of sexual assault. However, living with the long-term issues surrounding this violation can lead some to behaviour that negatively impacts their lives. Moreover, the modern society's focus on victim blaming helps many victims of rape become 
more susceptible to these negative impacts. This is due to the fact that these myths cause many rape survivors to feel responsible for their rape even as this is not the case.

Overall, whilst this thesis would be unwise to state that the way in which modern society deals with rape and rape victims is exactly the same to the way that the declamatory society or even the Roman society dealt with them, it is clear that there are several key parallels that can be made. A possible cause for these parallels is identified in Ward's writing when she states that the root cause of these rape myths that plague modern society are the patriarchal society from which they were created. ${ }^{184}$ This is to say that many of these myths are caused by an inherent misunderstanding as to what causes a rape. Recent scholarship has attempted to rectify the way in which we deal with rape, with the focus being placed upon how to help assist the survivor, with particular attention being placed upon their mental state, in order to help them deal with this horrific incident and learn to live with the complex array of issues that such an assault can cause. Whilst these movements are in the right direction on how to assist survivors it is clear that, when it comes to male victims, they are being under served in modern societies as they have been throughout history. In order for effective change to occur in the way in which society views, treats and ultimately helps victims of male sexual assault, it first needs to be acknowledged as equally important to instances of female sexual assault. This is to say that, regardless of the percentage difference in gender, rape is still rape and all cases should be treated equally and with equal focus and severity. It is through analysing the cases dealing with male rape in antiquity that we can come to better understand our own mistreatment and representation of this horrific act of coercion in modern times.

${ }^{184}$ Ward 1995:38 


\section{CONCLUSION}

As Gunderson noted, to offer a conclusion to a work centred around declamation almost seems in direct opposition to a genre that deliberately avoids such ideas. ${ }^{185}$ That being said, such is the way of academic writing that one must follow the rules it has established. To that end, the purpose of these closing remarks is to specifically highlight the three central points that this thesis has addressed.

The first of these directly reflects on the purpose of declamation as a whole. As illustrated in the first chapter, the place of declamation within scholarship has been contentious to say the least. Due to its purpose, style and function, declamation has been constantly labelled as a form of rhetoric that is simply not serious. Due to this simple fact, the analysis of declamation remains dormant at best with a reinvention of the way in which this school of rhetoric was viewed only occurring in recent scholarship. By choosing to cement the focus of this thesis' research upon declamation, moreover the social and societal implications of declamation, it has further supported the works of seminal scholars such as Gunderson to demonstrate the variety of ways that declamation can be utilised within modern scholarship. Ultimately, this thesis has shown that even a form of oratory considered to be no more than mere schoolboy antics ${ }^{186}$ can still provide a window through which one can discern what it meant to think and be Roman.

\footnotetext{
185 Gunderson 2003: 227

${ }^{186}$ Bloomer 1997b: 64-67
} 
The second point to be addressed is the place of male rape within scholarly discussions of sexual assault. As demonstrated throughout this thesis, to state that scholarship centred specifically on this form of assault pales in comparison to the depth focusing on female rape would be an understatement. In reality, this form of sexual assault is often considered an afterthought, if mentioned at all. Whilst it is perhaps unsurprising that this is the case, due to the large disparity of instances of sexual assault involving a woman, there is still much more that can and should be said about the topic that is going unexplored. Through assessing male rape through the lens of declamation, this thesis has shown that discussions of such a topic directly bring into question notions of masculinity, impenetrability and status. Moreover, in order to discuss such an attack, the Romans nearly always utilise the language of stuprum, illustrating that they viewed this attack as something abnormal and vile, even in comparison to other forms of rape. The victim is liable to be held morally responsible. The goal of this thesis is to open the doors for further exploration into scholarship centred on male rape with the hope that this discussion shall be only one of many that focus on the various nuances and implications that such a topic has to offer.

Finally, I would be remis to not restate the importance of the strong modern parallels that arose when analysing these declamatory cases. Said parallels help to illustrate the problematic way in which modern society deals with victims of sexual assault, specifically male ones. It has never been the goal of this writing to state that the way in which modern society approaches this topic is a direct one-to-one parallel with ancient Rome. However, the extent to which our society parallels key themes found in the ancient world shocked me. All of this is to restate the importance that studies of the ancient world can have on the way in which we go about informing and changing our current perspectives. Whilst it would be foolish to think that this thesis shall be the catalyst for widespread social change surrounding modern societies handling 
of victims, it is the hope of this thesis to help further inform the reader of the inherent flaws within our modern way of thinking.

To conclude, whilst this thesis by no means reinvents the wheel when it comes to analysis of sexual assault in the ancient world, it does serve the goal of shining a light on an underutilised source for analysing for topic, this being declamation. Furthermore, it focuses on an underexplored form of sexual assault in order to inform one of the various nuances that this topic provides that distinguishes it from the more widely studied alternative. Overall, this thesis has served to educate one in both of these fields of study and hopefully serve as the spark for further academic study in these fields. 


\section{BIBLIOGRAPHY}

\section{Primary Sources}

Antiphon Tetralogy 1, $2 \& 3$ (K. J. Maidment 1941)

Catullus Carmen (Micaela Wakil Janan 1994)

Cicero De Inventione (H. M. Hubbell 1949)

Philippics (D. R. Shackleton Bailey 2010)

Pro Milone (Erik Gunderson 2003)

Juvenal Satires (Susanna Morton Braund 2004)

Livy History of Rome (B. O. Foster 1919)

Plutarch Life of Galba (Bernadotte Perrin 1926)

Life of Marius (Rex Warner 1958)

Pseudo-Quintilian Major Declamations (Erik Gunderson 2003)

Quintilian Institutio Oratoria (Erik Gunderson 2003)

Seneca the Elder Controversiae (Michael Winterbottom 1974)

Suetonius Lives of the Caesars (J. C. Rolfe 1914) 
Valerius Maximus Memorable Doings \& Sayings (D. R. Shackleton Bailey 2000)

\section{Secondary Sources}

Abdullah-Khan, Noreen. 2008. Male Rape: The Emergence of a Social and Legal Issue. Palgrave Macmillan

Allen, Robert H. 2006. The Classical Origins of Modern Homophobia. MacFarland \& Company, Inc., Publishers

Anderson, William S. 1964. Anger in Juvenal and Seneca. University of California Press

Ando, Clifford. 2011. Law, Language, and Empire in the Roman Tradition. University of Pennsylvania Press

Arieti, James A. 1980. 'Empedocles in Rome: Rape and the Roman Ethos' Clio Vol. 10, 1-20

Arieti, James A. 1997. 'Rape and Livy's View of Roman History' Rape in Antiquity. Susan Deacy and Karen F. Pierce eds. The Classical Press of Whales 209-230

Bablitz, Leanne. 2007. Actors and Audience in the Roman Courtroom. Routledge Taylors \& Francis Group 
Bagley, Christopher and King, Kathleen 1991. Child Sexual Abuse: The Search for Healing. Routledge

Bailey, D. R. Shackleton. 1984. 'More on Pseudo-Quintilian's Declamations' Harvard Studies in Classical Philology. Vol. 88, 113-137

Bailey, D. R. Shackleton. 2010. Cicero Orations. Philippics 1-6. Harvard University Press

Bailey, D.R. Shackleton. 2000. Valerius Maximus: Memorable Doings and Sayings II. Harvard University Press

Beard, Mary. 1993. 'Looking (harder) for Roman Myth. Dumézil, Declamation and the Problems of Definition' Mythos in Mythenloser Desellschaft. Fritz Graf ed. 44-64

Berkowitz, Eric 2012. Sex and Punishment: 4000 Years of Judging Desires. The Westbourne Press

Bernstein, Neil W. 2013. Ethics, Identity, and Community in Later Roman Declamation. Oxford University Press

Berti, Emanuele. 2015. 'Law in Declamation: The Status Legales in Senecan Controversiae' Law and Ethics in Greek and Roman Declamation. Eugenio Amato, Francesco Citti and Bart Huelsenbeck eds. De Gruyter 7-34 
Berti, Emanuele. 2014. 'Le Controversiae Della Raccolta di Seneca Vecchio e la Dottrina Degli Status' University of California Press. A Journal of the History of Rhetoric. Vol. 32 No. 2, 99147

Blanshard, Alastair J. L. 2010. Sex: Vice and Love from Antiquity to Modernity. WileyBlackwell

Bloomer, W. Martin. 1997. Valerius Maximus and the Rhetoric of the New Nobility. The University of Carolina Press

Bloomer, W. Martin. 1997a. Latinity and Literary Society at Rome. University of Pennsylvania Press

Bloomer, W. Martin. 1997b. 'Schooling in Persona: Imagination and Subordination in Roman Education' Classical Antiquity. Vol. 16 No. 1 57-78

Bloomer, W. Martin. 2007. 'Roman Declamation: The Elder Seneca and Quintilian' $A$ Companion to Roman Rhetoric. William Dominik and Jon Hall eds. Blackwell Publishing 297306

Bonner, S. F. 1949. Roman Declamation in the Late Republic and Early Empire. University Press of Liverpool

Braund, Susanna Morton. 2004. Juvenal and Persius. Harvard University Press 
Breij, Bé. 2009. 'Pseudo-Quintilian's Major Declamations: Beyond School and Literature' Rhetorica: A Journal of the History of Rhetoric. Vol. 27 No. 3, 354-369

Breij, Bé. 2015. 'The Law in the Major Declamations Ascribed to Quintilian' Law and Ethics in Greek and Roman Declamation. Eugenio Amato, Francesco Citti and Bart Huelsenbeck eds. De Gruyter 219-247

Brescia, Graziana. 2015. 'Ambiguous Silence: Stuprum and Pudicitia in Latin Declamation' Law and Ethics in Greek and Roman Declamation. Eugenio Amato, Francesco Citti and Bart Huelsenbeck eds. De Gruyter 75-93

Briscoe, John. 1993. ‘Some Notes on Valerius Maximus' Sileno. Vol. 19, 395-408

Brownmiller, Susan. 1975. Against Our Will: Men, Women and Rape. Simon and Schuster Inc.

Bunzl, Martin. 2004. 'Counterfactual History: A User's Guide' The American Historical Review. Vol.3 845-858

Butrica, James. 2005. 'Some Myths and Anomalies in the Study of Roman Sexuality' SameSex Desire and Love in Graeco-Roman Antiquity and in the Classical Tradition of the West. Beert C. Verstraete and Vernon Provencal eds. Harrington Park Press 209-270

Calboli Montefusco, Lucia. 1986. La Dottrina Degli Status Nella Retorica Greca e Romana. Hildesheim: Olms 
Cantarella, Eva. 1992. Bisexuality in the Ancient World. Yale University Press

Carney, T. F. 1955. 'Notes on Plutarch's Life of Marius' The Classical Quarterly. Vol. 5 No.

$3,201-205$

Carney, T. F. 1967. A Biography of C. Marius. Royal VanGorcum Ltd

Chrystal, Paul. 2015. In Bed with the Romans. Amberley Publishing

Connolly, Joy. 2015. 'Imaginative Fiction Beyond Social and Moral Norms' Reading Roman

Declamation: The Declamations Ascribed to Quintilian. Martin T. Dinter ed. De Gruyter Inc. $191-208$

Craig, Christopher P. 2007. 'Cicero as Orator' A Companion to Roman Rhetoric William Dominik and Jon Hall eds. Blackwell Publishing Limited 264-284

Crook, John A. 1995. Legal Advocacy in the Roman World. Cornell University Press

Dinter, Martin T. 2015. Reading Roman Declamation: The Declamations Ascribed to Quintilian. De Gruyter Inc.

Dominik, William and Hall, Jon. 2007. 'Confronting Roman Rhetoric' A Companion to Roman Rhetoric. William Dominik and Jon Hall eds. Blackwell Publishing Limited 3-9

Dupont, Florence. 1989. Daily Life in Ancient Rome. Blackwell Publishing 
Edwards, Catherine. 1993. The Politics of Immorality in Ancient Rome. Cambridge University Press

Fantham, Elaine. 1991. 'Stuprum: Public Attitudes and Penalties for Sexual Offences in Republican Rome' Echos du Monde Classique: Classical Views. Vol. 35 No. 10, 267-291

Foster, B.O. 1919. Livy, In Fourteen Volumes I: Books I and II. Harvard University Press

Foxhall, Lin. 1999. 'Pandora Unbound: A Feminist Critique of Foucault's History of Sexuality' Rethinking Sexuality: Foucault and Classical Antiquity. David H. J Larmour, Paul Allen Miller and Charles Platter eds. Princeton University Press 122-137

Foxhall, Lin. 2013. Studying Gender in Classical Antiquity. Cambridge University Press

Glaser, Danya and Frosh Stephen. 1993. Child Sexual Abuse: Second Edition. Macmillan Press Limited

Gleason, Maud W. 1995. Making Men: Sophists and Self-Presentation in Ancient Rome. Princeton University Press

Griffin, Miriam. 1972. 'The Elder Seneca and Spain' Journal of Roman Studies. Vol. 62, 1-19

Grindstaff, David Allen. 2006. Rhetorical Secrets: Mapping Gay Identity and Queer Resistance in Contemporary America. The University of Alabama Press 
Gunderson, Erik. 2000. Staging Masculinity: The Rhetoric of Performance in the Roman World. The University of Michigan Press

Gunderson, Erik. 2003. Declamation, Paternity, and Roman Identity: Authority and the Rhetorical Self. Cambridge University Press

Håkanson, L. 1986. 'Die quintilianischen Deklamationen in der neueren Forschung.' Aufstieg und Niedergang der römischen Welt. Berlin, De Gruyter 2272-2306

Halperin, David M. 2002. 'The First Homosexuality?' The Sleep of Reason: Erotic Experience and Sexual Ethics in Ancient Greece and Rome. Martha C. Nussbaum and Juha Sihvola eds. The University of Chicago Press 229-268

Harries, Jill. 2007. Law and Crime in the Roman World: Key Themes in Ancient History. Cambridge University Press

Harvey, Brian K. 2016. Daily Life in Ancient Rome: A Sourcebook. Hackett Publishing Company

Holmes, Brooke. 2012. Gender: Antiquity and Its Legacy. I. B. Tauris

Hubbard, Thomas K. 2003. Homosexuality in Greece and Rome: A Sourcebook of Basic Documents. University of California Press 
Hubbell, H. M. 1949. Cicero: On Invention. The Best Kind of Orator Topics. Harvard University Press

Janan, Micaela. 1994. "When the Lamb Was Shattered" Desire and Narrative in Catullus. Southern Illinois University Press

Johnston, David. 1999. Roman Law in Context. Cambridge University Press

Kamen, Deborah. and Levin-Richardson, Sarah. 2014. 'Revisiting Roman Sexuality: Agency and the Conceptualisation of Penetrated Males' Sex in Antiquity: Exploring Gender and Sexuality in the Ancient World. M. Masterson, N. S. Rabinowitz. and J. Robson eds. Routledge Taylor \& Francis Group 449-460

Kamen, Deborah. and Levin-Richardson, Sarah. 2015. 'Lusty Ladies in the Roman Imaginary' Ancient Sex: New Essays. Ruby Blondell and Kirk Ormand eds. The Ohio State University Press $231-252$

Kellum, Barbara. 2003. 'Concealing/Revealing Gender and the Play of Meaning in the Monuments of Augustan Rome' Sex and Difference in Ancient Greece and Rome. Mark Golden \& Peter Toohey eds. Edinburgh University Press 276-289

Kenty, Joanna. 2016. 'Congenital Virtue: Mos Maiorum in Cicero's Orations' The Classical Journal. Vol. 111 No. 4, 429-462 
Kerremans, Bernt. 2016. 'Metus Gallicus, tumultus Cimbricus? The Possible Promulgation of a "tumultus" in the Cimbrian War (105-101 BCE) Mnemosyne. Vol. 69 622-841

Langer, Vera Isabella. 2007. Declamatio Romanorum. Dokument juristischer Argumentationstechnik, Fenster in die Gesellschaft ihrer Zeit und Quelle des Rechts?. Frankfurt am Main

Langlands, Rebecca. 2006. Sexual Morality in Ancient Rome. Cambridge University Press

Langlands, Rebecca. 2013. "Reading for the Moral" in Valerius Maximus: the Case of Severitas' The Cambridge Classical Journal. 160-187

Lewis, Andrew. 2015. 'Slavery, Family, and Status' The Cambridge Companion to Roman Law. David Johnston ed. Cambridge University Press 151-174

Li, C.K. West, D.J. and Woodhouse, T.P. 1990. Children's Sexual Encounters With Adults. Duckworth

Lopez, Jorge Fernández. 2007. 'Quintilian as Rhetorician and Teacher' A Companion to Roman Rhetoric. William Dominik and Jon Hall eds. 207-322

Maidment, K. J. 1941. Minor Attic Orators, Volume I: Antiphon. Harvard University Press

Marin, Jessica. 2011. Walton's Lives: Conformist Commemorations and the Rise of Biography. Oxford University Press 
Masterson, Mark. 2013. 'Studies of Ancient Masculinity' A Companion to Greek and Roman Sexualities. Thomas K. Hubbard ed. Wiley Blackwell 17-30

Masterson, Mark. 2014. Man to Man: Desire, Homosociality, and Authority in Late-Roman Manhood. The Ohio State University

McGinn, Thomas A. J. 1998. Prostitution, Sexuality, and the Law in Ancient Rome. Oxford University Press

Meyer, Elizabeth A. 2004. Legitimacy and Law in the Roman World: Tabulae in Roman Belief and Practice. Cambridge University Press

Moore, Casey C. 2013. 'Ancient and Modern Reappropriations of Homosexual Identity' the Comparatist, University of North Carolina Press. Vol. 37, 276-295

Mousourakis, George. 2007. A Legal History of Rome. Routledge Taylor \& Francis Group Neill, James. 2009. The Origins and Role of Same-Sex Relations in Human Societies. McFarland \& Company, Inc., Publishers

Nguyen, Nghiem L. 2006. 'Roman Rape: An Overview of Roman Rape Laws from the Republican Period to Justinian's Reign’ Michigan Journal of Gender \& Law. Vol. 13 Issue. 1, $75-112$ 
Niemi, Laura. and Young, Lane. 2014. 'Blaming the Victim in the Case of Rape' Taylor and Francis Group, LLC Psychological Inquiry. 230-233

Ogilvie, R. M. 1965. A Commentary on Livy Books 1-5. Oxford Clarendon Press

Olson, Kelly. 2014. 'Roman Sexuality and Gender' Themes in Roman Society and Culture: An Introduction to Ancient Rome. Matt Gibbs, Milorad Nikolic and Pauline Ripat eds. Oxford University Press 164-188

Ormand, Kirk. 2009. Controlling Desires: Sexuality in Ancient Greece and Rome. Praeger

Packman, Zola M. 1999. 'Rape and Consequences in the Latin Declamations' Studies in Classical Antiquity. 17-36

Perrin, Bernadotte. 1926. Plutarch Lives, Volume XI. Harvard University Press

Plessis, Paul Du. 2012. Studying Roman Law. Bristol Classical Press

Plummer, David. 1999. One of the Boys: Masculinity, Homophobia, and Modern Manhood. Harrington Park Press

Raphael, Jody. 2013. Rape is Rape: How Denial, Distortion, and Victim Blaming are Fuelling a Hidden Acquaintance Rape Crisis. Lawrence Hill Books 
Rhodes, Neil. 2000. 'The Controversial Plot: Declamation and the Concept of the "Problem Play"” The Modern Language Review. Vol. 95, No. 3, 609-622

Richlin, Amy. 1994. 'Not Before Homosexuality: The Materiality of the Cinaedus and the Roman Law against Love between Men' Journal of the History of Sexuality. Vol.3, No.4, 523573

Riggsby, Andrew M. 2010. Roman Law and the Legal World of the Romans. Cambridge University Press

Roberts, John. 2007. The Oxford Dictionary of the Classical World. Oxford University Press

Robinson, Peter. 2008. The Changing World of Gay Men. Palgrave Macmillam

Rolfe, J. C. 1914. Suetonius, Lives of the Caesars. Harvard University Press

Roller, M. 1997. 'Color-Blindness: Cicero's Death, Declamation, and the Production of History.' Classical Philology. Vol. 92, 109-130

Roller, M. 2009. 'The Exemplary Past in Roman Historiography and Culture.' The Cambridge Companion to the Roman Historians. A. Feldherr ed. New York 214-230

Russell, D. A. 1966. 'On Reading Plutarch's “Lives”' Greece \& Rome. Vol. 13 No. 2, 139-154

Russell, D. A. 1983. Greek Declamation. Cambridge University Press 
Russell, D. A. 1996. Libanius: Imaginary Speeches. A Selection of Declamations. London. Duckworth

Santangelo, Federico. 2016. Marius. Bloomsbury Publishing

Shumka, Leslie. 2014. 'Roman Slavery' Themes in Roman Society and Culture: An Introduction to Ancient Rome. Matt Gibbs, Milorad Nikolic and Pauline Ripat eds. Oxford University Press 72-93

Sissa, Giulia. 2008. Sex and Sensuality in the Ancient World. Yale University Press

Skaine, Rosemarie. 2015. Abuse: An Encyclopedia of Causes, Consequences, and Treatments. ABC-CLIO, LLC

Skinner, Marilyn B. 2005. Sexuality in Greek and Roman Culture. Malden: Blackwell

Skinner, Marilyn B. 2014. Sexuality in Greek and Roman Culture: Second Edition. Wiley Blackwell

Stewart, W. J. 2006. Collins Dictionary of Law, $3^{\text {rd }}$ Edition. Collins

Suarez, Eliana. and Gadalla, Tahany, M. 2010. 'Stop Blaming the Victim: A Meta-Analysis of Rape Myths' Journal of Interpersonal Violence. 2010-2035 
Sussman, Lewis A. 1971. 'The Artist Unity of the Elder Seneca's First Preface and the Controversiae as a Whole' The American Journal of Philology. Vol. 92, No. 2, 285-291

Sussman, Lewis A. 1978. The Elder Seneca. Leiden Brill

Sussman, Lewis A. 1987. The Major Declamations Ascribed to Quintilian: A Translation. Frankfurt

Sussman, Lewis A. 1995. 'Sons and Fathers in the Major Declamations Ascribed to Quintilian' The International Society for the History of Rhetoric. Vol. 13 No. 2, 179-192

Treble, H. A. \& King, K. M. 1930. Everyday Life in Rome in the Time of Caesar and Cicero. Oxford at the Clarendon Press

Tröster, Manuel. 2012. "Plutarch and "Mos Maiorum" in the "Life of Aemilius Paullus"" Peeters Publishers Ancient Society. Vol. 42, 219-254

Ullman, Sarah E. 2010. Talking About Sexual Assault: Society's Response to Survivors. American Psychological Association

Walters, Jonathan. 1997. 'Invading the Roman Body: Manliness and Impenetrability in Roman Thought' Roman Sexualities. Judith P. Hallett and Marilyn B. Skinner eds. Princeton University Press 29-46 
Ward, Colleen A. 1995. Attitudes Toward Rape: Feminist and Social Psychological Perspectives. SAGE Publications

Warner, Rex. 1958. Plutarch: Fall of the Roman Republic. Penguin Group

Williams, Craig A. 1999. Roman Homosexuality: Ideologies of Masculinity in Classical Antiquity. Cambridge University Press

Williams, Craig A. 2010. Roman Homosexuality: Second Edition. Oxford University Press

Williamson, Callie. 2005. The Laws of the Roman People: Public Law in the Expansion and Decline of the Roman Republic. The University of Michigan Press

Winterbottom, Michael. 1974. The Elder Seneca: Declamations in Two Volumes. Volume I. Harvard University Press

Younger, John G. 2004. Sex in the Ancient World from A to Z. Routledge Taylor \& Francis Group 